\title{
Applied methods for studying the relationship between climatic factors and cotton production
}

\author{
Zakaria M. Sawan \\ Cotton Research Institute, Agricultural Research Center, Ministry of Agriculture \& Land Reclamation, Giza, Egypt; \\ zmsawan@hotmail.com
}

Received 2 August 2013; revised 12 September 2013; accepted 1 October 2013

Copyright (C) 2013 Zakaria M. Sawan. This is an open access article distributed under the Creative Commons Attribution License, which permits unrestricted use, distribution, and reproduction in any medium, provided the original work is properly cited.

\section{ABSTRACT}

This study investigates the statistical relationship between climatic variables and aspects of cotton production (G. barbadense), and the effects of climatic factors prevailing prior to flowering or subsequent to boll setting on flower and boll production and retention in cotton. The effects of specific climatic factors during both preand post-anthesis periods on boll production and retention are mostly unknown. However, by determining the relationship of climatic factors with flower and boll production and retention, the overall level of production can be possibly predicted. Thus, an understanding of these relationships may help physiologists determine control mechanisms of production in cotton plants. Also, the study covers the predicted effects of climatic factors during convenient intervals (in days) on cotton flower and boll production compared with daily observations. Further, cotton flower and boll production as affected by climatic factors and soil moisture status has been considered. Evaporation, sunshine duration, relative humidity, surface soil temperature at $1800 \mathrm{~h}$, and maximum air temperature, are the important climatic factors that significantly affect flower and boll production. The least important variables were found to be surface soil temperature at $600 \mathrm{~h}$ and minimum temperature. The five-day interval was found to be more adequately and sensibly related to yield parameters. Evaporation, minimum humidity and sunshine duration were the most effective climatic factors during preceding and succeeding periods on boll production and retention. There was a negative correlation between flower number and boll production and either evaporation or sunshine duration, while that correlation with minimum relative humidity was positive. The soil moisture status showed low and insignificant correlation with flower and boll production. Higher minimum relative humidity, short period of sunshine duration, and low temperatures enhanced flower and boll formation.

Keywords: Cotton Flower and Boll Production; Boll Retention; Evaporation; Relative Humidity; Soil Moisture Status; Sunshine Duration; Temperature

\section{INTRODUCTION}

Climate affects crop growth interactively, sometimes resulting in unexpected responses to prevailing conditions. Many factors, such as length of the growing season, climate (including solar radiation, temperature, light, wind, rainfall, and dew), cultivar, availability of nutrients and soil moisture, pests and cultural practices affect cotton growth [1]. The balance between vegetative and reproductive development can be influenced by soil fertility, soil moisture, cloudy weather, spacing and perhaps other factors such as temperature and relative humidity [2]. Weather, soil, cultivars, and cultural practices affect crop growth interactively, sometimes resulting in plants responding in unexpected ways to their conditions [3].

Water is a primary factor controlling plant growth. Xiao et al. [4] stated that, when water was applied at $0.85,0.70,0.55$ or $0.40 \mathrm{ET}$ (evapotranspiration) to cotton plants grown in pots, there was a close relationship between plant development and water supply. The fruitbearing branches, square and boll numbers and boll size were increased with increased water supply. Barbour and Farquhar [5] reported on greenhouse pot trials where cotton cv. CS50 plants were grown at $43 \%$ or $76 \%$ relative humidity $(\mathrm{RH})$ and sprayed daily with abscisic acid (ABA) or distilled water. Plants grown at lower RH had higher transpiration rates, lower leaf temperatures and lower stomatal conductance. Plant biomass was also re- 
duced at the lower RH. Within each RH environment, increasing ABA concentration generally reduced stomatal conductance, evaporation rates, superficial leaf density and plant biomass, and increased leaf temperature and specific leaf area.

Temperature is also a primary factor controlling rates of plant growth and development. Reddy et al. [6] in growth chamber experiments found that Pima cotton cv. S-6 produced lower total biomass at $35.5^{\circ} \mathrm{C}$ than at $26.9^{\circ} \mathrm{C}$ and no bolls were produced at the higher temperature of $40^{\circ} \mathrm{C}$. Schrader et al. [7] stated that high temperatures that plants are likely to experience inhibit photosynthesis. Zhou et al. [8] indicated that light duration is the key meteorological factor influencing the wheatcotton cropping pattern and position of the bolls, while temperature had an important function on upper (node 7 to 9) and top (node 10) bolls, especially for double cropping patterns with early maturing varieties. Fisher [9] found that high temperatures can cause male sterility in cotton flowers, and could have caused increased boll shedding in the late fruiting season. Zhao [10] indicated that temperature was the main climatic factor affecting cotton production and $20^{\circ} \mathrm{C}-30^{\circ} \mathrm{C}$ was the optimum temperature for cotton growth. Reddy et al. [11] found that when Upland cotton (G. hirsutum) cv. DPL-51 was grown in naturally lit plant growth chambers at $30 / 22^{\circ} \mathrm{C}$ day/night temperatures from sowing until flower bud production, and at 20/12, 25/17, 30/22, 35/27 and $40 / 32^{\circ} \mathrm{C}$ for 42 days after flower bud production, fruit retention was severely curtailed at the two higher temperatures compared with $30 / 22^{\circ} \mathrm{C}$. Species/cultivars that retain fruits at high temperatures would be more productive both in the present-day cotton production environments and even more in future warmer world.

The objectives of this investigation: 1) Aim at predicting effects of climatic factors during different convenient intervals (in days) on cotton flower and boll production compared with daily observations. The study presents a rich effort focused on evaluating the efficacy of regression equations between cotton crop data and climatic data grouped at different time intervals, to determine the appropriate time scale for aggregating climate data to be used for predicting flower and boll production in cotton [12]. 2) Also, collect information about the nature of the relationship between various climatic factors and cotton boll development and the 15-day period both prior to and after initiation of individual bolls of field grown cotton plants in Egypt. This could pave the way for formulating advanced predictions as for the effect of certain climatic conditions on production of Egyptian cotton. It would be useful to minimize the deleterious effects of the factors through utilizing proper cultural practices which would limit and control their negative effects, and this will lead to an improvement in cotton yield [13]. 3) Further, provide information on the effect of various climatic factors and soil moisture status during the development stage on flower and boll production in Egyptian cotton. This could result in formulating advanced predictions as for the effect of certain climatic conditions on production of Egyptian cotton. Minimizing the deleterious effects of the factors through utilizing proper cultural practices will lead to improved cotton yield [14].

\section{MATERIALS and METHODS}

Two uniform field trials were conducted at the experimental farm of the Agricultural Research Center, Ministry of Agriculture, Giza, Egypt $\left(30^{\circ} \mathrm{N}, 31^{\circ}: 28^{\prime} \mathrm{E}\right.$ at an altitude of $19 \mathrm{~m}$ ), using the cotton cultivar Giza 75 (Gossypium barbadense L.) in 2 successive seasons (I and II). The soil texture was a clay loam, with an alluvial substratum $(\mathrm{pH}=8.07,42.13 \%$ clay, $27.35 \%$ silt, $22.54 \%$ fine sand, $3.22 \%$ coarse sand, $2.94 \%$ calcium carbonate and $1.70 \%$ organic matter) [14].

In Egypt, there are no rain-fed areas for cultivating cotton. Water for the field trials was applied using surface irrigation. Total water consumed during each of two growing seasons supplied by surface irrigation was about $6000 \mathrm{~m}^{3} \cdot \mathrm{h}^{-1}$. The criteria used to determine amount of water applied to the crop depended on soil water status. Irrigation was applied when soil water content reached about $35 \%$ of field capacity $(0-60 \mathrm{~cm})$. In season I, the field was irrigated on 15 March (at planting), 8 April (first irrigation), 29 April, 17 May, 31 May, 14 June, 1 July, 16 July, and 12 August. In season II, the field was irrigated on 23 March (planting date), 20 April (first irrigation), 8 May, 22 May, 1 June, 18 June, 3 July, 20 July, 7 August and 28 August. Techniques normally used for growing cotton in Egypt were followed. Each experimental plot contained 13 to 15 ridges to facilitate proper surface irrigation. Ridge width was $60 \mathrm{~cm}$ and length was $4 \mathrm{~m}$. Seeds were sown on 15 and 23 March in Seasons I and II, respectively, in hills $20 \mathrm{~cm}$ apart on one side of the ridge. Seedlings were thinned to 2 plants per hill 6 weeks after planting, resulting in a plant density of about 166,000 plants ha ${ }^{-1}$. Phosphorus fertilizer was applied at a rate of $54 \mathrm{~kg} \mathrm{P}_{2} \mathrm{O}_{5} \mathrm{ha}^{-1}$ as calcium super phosphate during land preparation. Potassium fertilizer was applied at a rate of $57 \mathrm{~kg} \mathrm{~K}_{2} \mathrm{O} \mathrm{ha}^{-1}$ as potassium sulfate before the first irrigation (as a concentrated band close to the seed ridge). Nitrogen fertilizer was applied at a rate of $144 \mathrm{~kg} \mathrm{~N} \mathrm{ha}{ }^{-1}$ as ammonium nitrate in two equal doses: the first was applied after thinning just before the second irrigation and the second was applied before the third irrigation. Rates of phosphorus, potassium, and nitrogen fertilizer were the same in both seasons. These amounts were determined based on the use of soil tests [14]. 
After thinning, 261 and 358 plants were randomly selected (precaution of border effect was taken into consideration by discarding the cotton plants in the first and last two hills of each ridge) from 9 and 11 inner ridges of the plot in seasons I and II respectively. Pest control management was carried out on an-as-needed basis, according to the local practices performed at the experimental. Flowers on all selected plants were tagged in order to count and record the number of open flowers, and set bolls on a daily basis. The flowering season commenced on the date of the first flower appearance and continued until the end of flowering season $(31 \mathrm{Au}-$ gust). The period of whole September (30 days) until the $20^{\text {th }}$ of October (harvest date) allowed a minimum of 50 days to develop mature bolls. In season I, the flowering period extended from 17 June to 31 August, whereas in season II, the flowering period was from 21 June to 31 August. Flowers produced after 31 August were not expected to form sound harvestable bolls, and therefore were not taken into account [14].

For statistical analysis, the following data of the dependent variables were collected: number of tagged flowers separately counted each day on all selected plants $\left(\mathrm{Y}_{1}\right)$, number of retained bolls obtained from the total daily tagged flowers on all selected plants at harvest $\left(\mathrm{Y}_{2}\right)$, and $\left(\mathrm{Y}_{3}\right)$ percentage of boll retention ([number of retained bolls obtained from the total number of daily tagged flowers in all selected plants at harvest]/[daily number of tagged flowers on each day in all selected plants $] \times 100$ ). As a rule, observations were recorded when the number of flowers on a given day was at least 5 flowers found in a population of 100 plants and this continued for at least five consecutive days. This rule omitted eight observations in the first season and ten observations in the second season. The number of observations (n) was 68 (23 June through 29 August) and 62 (29 June through 29 August) for the two seasons, respectively. Variables of the soil moisture status considered were, the day prior to irrigation, the day of irrigation, and the first and second days after the day of irrigation [14].

The climatic factors (independent variables) considered were daily data of: maximum air temperature $\left({ }^{\circ} \mathrm{C}\right.$, $\left.\mathrm{X}_{1}\right)$; minimum air temperature $\left({ }^{\circ} \mathrm{C}, \mathrm{X}_{2}\right)$; maximumminimum air temperature (diurnal temperature range) $\left({ }^{\circ} \mathrm{C}, \mathrm{X}_{3}\right)$; evaporation (expressed as Piche evaporation) $\left(\mathrm{mm} \cdot \mathrm{day}^{-1}, \mathrm{X}_{4}\right)$; surface soil temperature, grass temperature or green cover temperature at $600 \mathrm{~h}\left({ }^{\circ} \mathrm{C}, \mathrm{X}_{5}\right)$ and $1800 \mathrm{~h}\left({ }^{\circ} \mathrm{C}, \mathrm{X}_{6}\right)$; sunshine duration $\left(\mathrm{h} \cdot \mathrm{day}^{-1}, \mathrm{X}_{7}\right)$; maximum relative humidity $(\max \mathrm{RH})\left(\%, \mathrm{X}_{8}\right)$, minimum relative humidity $(\min \mathrm{RH})\left(\%, \mathrm{X}_{9}\right)$ and wind speed $\left(\mathrm{m} \cdot \mathrm{s}^{-1}, \mathrm{X}_{10}\right)$ in season II only. The source of the climatic data was the Agricultural Meteorological Station of the Agricultural Research Station, Agricultural Research Center, Giza, Egypt. No rainfall occurred during the two growing seasons [13].

Daily records of the climatic factors (independent variables), were taken for each day during production stage in any season including two additional periods of 15 days preceding and after the production stage. Range and mean values of the climatic parameters recorded during the production stage for both seasons and overall data are listed in Table 1. Daily number of flowers and number of bolls per plant which survived till maturity (dependent variables) during the production stage in the two seasons are graphically illustrated in Figures $\mathbf{1}$ and $\mathbf{2}$ [14].

\section{RESULTS AND DISCUSSION}

\subsection{Appropriate Time Scale for Aggregating Climatic Data to Predict Flowering and Boll Setting of Cotton}

Statistical analysis was conducted using the procedures outlined in the general linear model (GLM) [15]. Data of dependent and independent variables, collected for each day of the production stage (60 days in each season), were summed up into intervals of 2, 3, 4, 5, 6 or 10 days. Data from these intervals were used to compute relationships between the dependent variables (flower and boll setting and boll retention) and the independent variables (climatic factors) in the form of simple correlation coefficients for each season. Comparisons between the values of " $r$ " were done to determine the best interval of days for determining effective relationships. The $\alpha$ level for significance was $P \leq 0.15$. The climatic factors attaining a probability level of significance not exceeding 0.15 were deemed important (affecting the dependent variables), selected and combined with dependent variable in multiple regression analysis to obtain a convenient predictive equation [16]. Multiple linear regression equations (using stepwise method) comprising selected predictive variables were computed for the determined interval and coefficients of multiple determinations $\left(R^{2}\right)$ were calculated to measure the efficiency of the regression models in explaining the variation in data [12]. Correlation and regression analyses were computed according to Draper and Smith [17].

\subsubsection{Correlation Estimates}

Significant simple correlation coefficients were estimated between the production variables and studied climatic factors for different intervals of days (combined data of the 2 seasons) (Table 2) [12].

Evaporation was the most important climatic factor affecting flower and boll production in Egyptian cotton. The negative correlation means that high evaporation ratio significantly reduced flower and boll production. High evaporation rates could result in water stress that 
Table 1. Range and mean values of the independent variables for the two seasons and over all data.

\begin{tabular}{ccccccc}
\hline \multirow{2}{*}{ Climatic factor's } & \multicolumn{2}{c}{ First season } & \multicolumn{2}{c}{ Second season ${ }^{* *}$} & \multicolumn{2}{c}{ Over all data (Two seasons) } \\
\cline { 2 - 7 } & Range & Mean & Range & Mean & Range & Mean \\
\hline Max Temp $\left({ }^{\circ} \mathrm{C}\right),\left(\mathrm{X}_{1}\right)$ & $31.0-44.0$ & 34.3 & $30.6-38.8$ & 34.1 & $30.6-44.0$ & 34.2 \\
Min Temp $\left({ }^{\circ} \mathrm{C}\right),\left(\mathrm{X}_{2}\right)$ & $18.6-24.5$ & 21.9 & $18.4-23.9$ & 21.8 & $18.4-24.5$ & 21.8 \\
Max-Min Temp $\left({ }^{\circ} \mathrm{C}\right),\left(\mathrm{X}_{3}\right)^{*}$ & $9.4-20.9$ & 12.4 & $8.5-17.6$ & 12.2 & $8.5-20.9$ & 12.3 \\
Evap $\left(\mathrm{mm} \cdot \mathrm{d}^{-1}\right),\left(\mathrm{X}_{4}\right)$ & $7.6-15.2$ & 10.0 & $4.1-9.8$ & 6.0 & $4.1-15.2$ & 8.0 \\
$600 \mathrm{~h} \mathrm{Temp}\left({ }^{\circ} \mathrm{C}\right),\left(\mathrm{X}_{5}\right)$ & $14.0-21.5$ & 17.8 & $13.3-22.4$ & 18.0 & $13.3-22.4$ & 17.9 \\
$1800 \mathrm{~h} \mathrm{Temp}\left({ }^{\circ} \mathrm{C}\right),\left(\mathrm{X}_{6}\right)$ & $19.6-27.0$ & 24.0 & $20.6-27.4$ & 24.2 & $19.6-27.4$ & 24.1 \\
Sunshine $\left(\mathrm{h} \cdot \mathrm{d}^{-1}\right),\left(\mathrm{X}_{7}\right)$ & $10.3-12.9$ & 11.7 & $9.7-13.0$ & 11.9 & $9.7-13.0$ & 11.8 \\
Max RH $(\%),\left(\mathrm{X}_{8}\right)$ & $62-96$ & 85.4 & $51-84$ & 73.2 & $51-96$ & 79.6 \\
Min RH $(\%),\left(\mathrm{X}_{9}\right)$ & $11-45$ & 30.8 & $23-52$ & 39.8 & $11-52$ & 35.1 \\
Wind speed $\left(\mathrm{m} \cdot \mathrm{s}^{-1}\right),\left(\mathrm{X}_{10}\right)$ & $\mathrm{ND}$ & $\mathrm{ND}$ & $2.2-7.8$ & 4.6 & $\mathrm{ND}$ & $\mathrm{ND}$ \\
\hline
\end{tabular}

"Diurnal temperature range. ND not determined. ${ }^{*}$ Flower and boll stage (68 days, from 23 June through 29 August). ${ }^{* *}$ Flower and boll stage (62 days, from 29 June through 29 August). Sawan et al. [12].

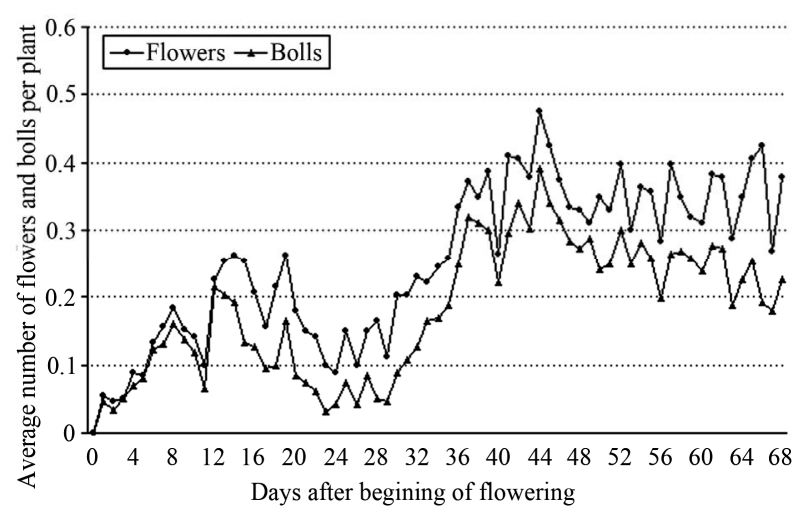

Figure 1. Daily number of flowers and bolls during the production stage (68 days) in the first season (I) for the Egyptian cotton cultivar Giza 75 (Gossypium barbadense L.) grown in uniform field trial at the experimental farm of the Agricultural Research Centre, Giza $\left(30^{\circ} \mathrm{N}, 31^{\circ}: 28^{\prime} \mathrm{E}\right)$, Egypt. The soil texture was a clay loam, with an alluvial substratum, $(\mathrm{pH}=8.07)$. Total water consumptive use during the growing season supplied by surface irrigation was about $6000 \mathrm{~m}^{3} \cdot \mathrm{ha}^{-1}$. No rainfall occurred during the growing season. The sampling size was 261 plants [14]

would slow growth and increase shedding rate of flowers and bolls [12]. Kaur and Singh [18] found in cotton that flower number was decreased by water stress, particularly when existing at flowering stage. Seed cotton yield was decreased by about $50 \%$ when water stress was present at flowering stage, slightly decreased by stress at boll formation stage, and not significantly affected by stress in the vegetative stage (6 - 7 weeks after sowing). The second most important climatic factor was minimum humidity, which had a high positive correlation with flower and boll production, and retention ratio. The positive correlation means that increased humidity would bring about better boll production. The third most important climatic factor in our study was sunshine duration, which showed a significant negative relationship with flower and boll production only [12]. The negative relationship between sunshine duration and cotton pro-

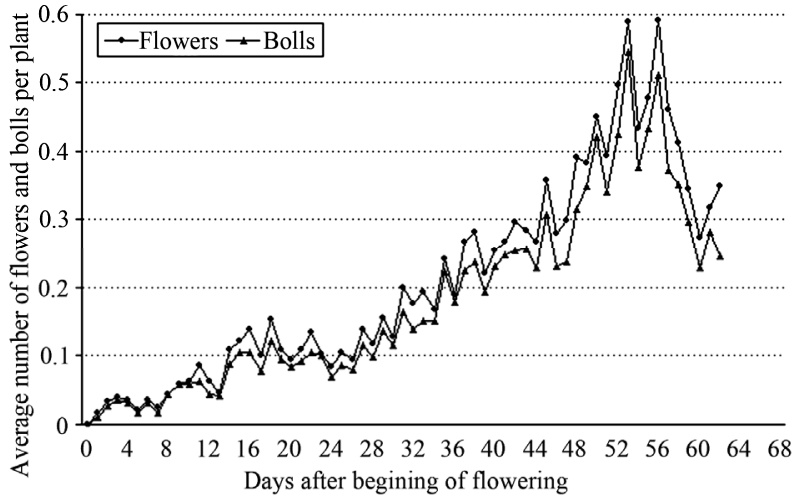

Figure 2. Daily number of flowers and bolls during the production stage (62 days) in the second season (II) for the Egyptian cotton cultivar Giza 75 (Gossypium barbadense L.) grown in uniform field trial at the experimental farm of the Agricultural Research Centre, Giza $\left(30^{\circ} \mathrm{N}, 31^{\circ}: 28^{\prime} \mathrm{E}\right)$, Egypt. The soil texture was a clay loam, with an alluvial substratum, $(\mathrm{pH}=$ 8.07 ). Total water consumptive use during the growing season supplied by surface irrigation was about $6000 \mathrm{~m}^{3} \cdot \mathrm{ha}^{-1}$. No rainfall occurred during the growing season. The sampling size was 358 plants [14].

duction may be due to the fact that the species of the genus Gossypium are known to be short day plants [19], so, an increase of sunshine duration above that sufficient to attain good plant growth will decrease flower and boll production. Bhatt [20] found that exposure to daylight over 14 hours and high day temperature, individually or in combination, delayed flowering of the Upland cotton cv. J34. Although average sunshine duration in our study was only $11.7 \mathrm{~h}$, yet it could reach $13 \mathrm{~h}$, which, in combination with high maximum temperatures (up to $38.8^{\circ} \mathrm{C}$ ), may have adversely affected reproductive growth.

Maximum air temperature, temperature magnitude and surface soil temperature at $1800 \mathrm{~h}$ show significant negative relationships with flower and boll production only. Meanwhile, the least important factors were surface soil temperature at $600 \mathrm{~h}$ and minimum air temperature [12]. 
Table 2. Significant simple correlation coefficient values between the production variables and the studied climatic factors for the daily and different intervals of days combined over both seasons.

\begin{tabular}{|c|c|c|c|c|c|c|c|c|c|c|}
\hline \multirow{3}{*}{$\begin{array}{c}\text { Daily and } \\
\text { intervals } \\
\text { of days }\end{array}$} & \multirow{3}{*}{$\begin{array}{l}\text { Production } \\
\text { variables }\end{array}$} & \multicolumn{9}{|c|}{ Climatic factors $^{\mathrm{z}}$} \\
\hline & & \multicolumn{3}{|c|}{ Air temp $\left({ }^{\circ} \mathrm{C}\right)$} & \multirow{2}{*}{$\begin{array}{c}\text { Evap } \\
\left(\mathrm{mm}^{-1} \mathrm{~d}^{-1}\right) \\
\left(\mathrm{X}_{4}\right)\end{array}$} & \multicolumn{2}{|c|}{ Surface soil temp $\left({ }^{\circ} \mathrm{C}\right)$} & \multirow{2}{*}{$\begin{array}{c}\text { Sunshine } \\
\text { duration } \\
\left(\mathrm{h} \cdot \mathrm{d}^{-1}\right)\left(\mathrm{X}_{7}\right)\end{array}$} & \multicolumn{2}{|c|}{ Relative humidity (\%) } \\
\hline & & $\operatorname{Max}\left(\mathrm{X}_{1}\right)$ & $\operatorname{Min}\left(X_{2}\right)$ & $\operatorname{Max}-\operatorname{Min}\left(\mathrm{X}_{3}\right)$ & & $600 \mathrm{~h}\left(\mathrm{X}_{5}\right)$ & $1800 \mathrm{~h}\left(\mathrm{X}_{6}\right)$ & & $\operatorname{Max}\left(\mathrm{X}_{8}\right)$ & $\operatorname{Min}\left(\mathrm{X}_{9}\right)$ \\
\hline \multirow{3}{*}{ Daily $(n=120)$} & Flower & $-0.15^{++}$ & NS & $-0.26^{* *}$ & $-0.33^{* *}$ & NS & $-0.20^{*}$ & $-0.23^{*}$ & NS & $0.30^{* *}$ \\
\hline & Boll & NS & NS & $-0.25^{* *}$ & $-0.43^{* *}$ & NS & $-0.19^{++}$ & $-0.18^{++}$ & NS & $0.36^{* *}$ \\
\hline & Boll ret. rat. & NS & NS & NS & $-0.56^{* *}$ & NS & NS & NS & NS & $0.34^{* *}$ \\
\hline \multirow{3}{*}{2 Days $\left(n^{\#}=60\right)$} & Flower & $-0.31^{++}$ & NS & $-0.32^{*}$ & $-0.36^{* *}$ & NS & $-0.24^{+}$ & $-0.36^{* *}$ & NS & $0.37^{* *}$ \\
\hline & Boll & $-0.29^{++}$ & NS & $-0.30^{++}$ & $-0.46^{* *}$ & NS & $-0.21^{+}$ & $-0.31^{*}$ & NS & $0.44^{* *}$ \\
\hline & Boll ret. rat. & NS & NS & NS & $-0.61^{* *}$ & NS & NS & NS & NS & $0.40^{* *}$ \\
\hline \multirow{3}{*}{3 Days $\left(n^{\#}=40\right)$} & Flower & $-0.34^{*}$ & NS & $-0.34^{*}$ & $-0.33^{*}$ & NS & $-0.28^{++}$ & $-0.39^{*}$ & NS & $0.34^{*}$ \\
\hline & Boll & $-0.32^{*}$ & NS & $-0.32^{*}$ & $-0.48^{* *}$ & NS & $-0.24^{+}$ & $-0.36^{*}$ & NS & $0.45^{* *}$ \\
\hline & Boll ret. rat. & NS & NS & NS & $-0.63^{* *}$ & NS & NS & NS & NS & $0.40^{*}$ \\
\hline \multirow{3}{*}{4 Days $\left(n^{\#}=30\right)$} & Flower & $-0.31^{++}$ & NS & $-0.35^{++}$ & $-0.33^{++}$ & NS & $-0.28^{+}$ & $-0.39^{*}$ & NS & $0.34^{++}$ \\
\hline & Boll & $-0.31^{++}$ & NS & $-0.33^{++}$ & $-0.48^{* *}$ & NS & $-0.23^{+}$ & $-0.38^{*}$ & NS & $0.45^{*}$ \\
\hline & Boll ret. rat. & NS & NS & NS & $-0.64^{* *}$ & NS & NS & NS & NS & $0.42^{*}$ \\
\hline \multirow{3}{*}{5 Days $\left(n^{\#}=24\right)$} & Flower & $-0.35^{++}$ & NS & $-0.37^{++}$ & $-0.39^{++}$ & NS & $-0.39^{++}$ & $-0.52^{* *}$ & NS & $0.41^{*}$ \\
\hline & Boll & $-0.33^{+}$ & NS & $-0.35^{++}$ & $-0.49^{*}$ & NS & $-0.35^{++}$ & $-0.44^{*}$ & NS & $0.47^{* *}$ \\
\hline & Boll ret. rat. & NS & NS & NS & $-0.66^{* *}$ & NS & NS & NS & NS & $0.43^{*}$ \\
\hline \multirow{3}{*}{6 Days $\left(n^{\#}=20\right)$} & Flower & $-0.37^{++}$ & NS & $-0.41^{++}$ & $-0.38^{++}$ & NS & NS & $-0.54^{* *}$ & NS & $0.42^{*}$ \\
\hline & Boll & $-0.37^{++}$ & NS & $-0.40^{++}$ & $-0.49^{*}$ & NS & NS & $-0.46^{*}$ & NS & $0.49^{*}$ \\
\hline & Boll ret. rat. & NS & NS & NS & $-0.69^{* *}$ & NS & NS & NS & NS & $0.45^{*}$ \\
\hline \multirow{3}{*}{10 Days $\left(n^{\#}=12\right)$} & Flower & NS & NS & $-0.45^{++}$ & $-0.40^{+}$ & NS & $-0.55^{*}$ & $-0.65^{*}$ & NS & $0.43^{++}$ \\
\hline & Boll & NS & NS & $-0.43^{++}$ & $-0.51^{++}$ & NS & $-0.53^{++}$ & $-0.57^{*}$ & NS & $0.51^{++}$ \\
\hline & Boll ret. rat. & NS & NS & NS & $-0.74^{* *}$ & NS & NS & NS & NS & $0.55^{*}$ \\
\hline
\end{tabular}

${ }^{\mathrm{z}}$ Wind speed did not show significant effect upon the studied production variables, so is not reported. ${ }^{* *}$ Significant at $1 \%$ probability level, ${ }^{*}$ Significant at $5 \%$ probability level. ${ }^{++}$Significant at $10 \%$ probability level, ${ }^{+}$Significant at $15 \%$ probability level. NS: Means simple correlation coefficient is not significant at the $15 \%$ probability level. ${ }^{*} n=$ Number of data pairs used in calculation. Sawan et al. [12].

Our results indicate that evaporation was the most effective climatic factor affecting cotton boll production. As the sign of the relationship was negative, this means that an increase in evaporation caused a significant reduction in boll number [12]. Thus, applying specific treatments, such as an additional irrigation or the use of plant growth regulators (PGR) that would decrease the deleterious effect of evaporation after boll formation, could contribute to an increase in cotton boll production and retention, and consequently an increase in cotton yield. In this connection, Meek et al. [21] in a field experiment in Arkansas found that application of 3 or $6 \mathrm{~kg}$ glycine betaine (PGR) ha ${ }^{-1}$ to cotton plants under mild water stress increased yield.

Comparing results for the different intervals of days with those from daily observation (Table 2), the 5-day interval appeared to be the most suitable interval, which actually revealed a more solid and more obvious relationships between climatic factors and production characters. This was in fact indicated by the higher $R^{2}$ values obtained when using the 5-day intervals. The 5-day interval may be the most suitable interval for diminishing the daily fluctuations between the factors under study to clear these relations comparing with the other intervals. However, it seems that this conception is true provided that the fluctuations in climatic conditions are limited or minimal. Therefore, it would be the most efficient interval used to help circumvent the unfavorable effect of climatic factors. This finding gives researchers and producers a chance to deal with condensed rather than daily weather data [12].

\subsubsection{Regression Models}

Multiple linear regression equations were estimated using the stepwise multiple regression technique to express the relation between cotton production variables [number of flowers $\left(\mathrm{Y}_{1}\right)$; bolls per plant $\left(\mathrm{Y}_{2}\right)$; and boll retention ratio $\left.\left(\mathrm{Y}_{3}\right)\right]$ and the studied climatic factors (Table 3) [12].

Evaporation and surface soil temperature at $1800 \mathrm{~h}$, sunshine duration and minimum humidity accounted for a highly significant amount of variation $(P<0.05)$ in cotton production variables, with the equation obtained for the 5-day interval showing a high degree of certainty. 
Table 3. The equations obtained for each of the studied cotton production variables for the five-day intervals and daily intervals combined over both seasons.

\begin{tabular}{|c|c|c|}
\hline Equation $^{z}$ & $R^{2}$ & Significance \\
\hline \multicolumn{3}{|l|}{ Five-day intervals } \\
\hline $\begin{aligned} \mathrm{Y}_{1}= & 23.78-0.5362 \mathrm{X}_{4}-0.1429 \mathrm{X}_{6} \\
& -0.1654 \mathrm{X}_{7}+0.0613 \mathrm{X}_{9}\end{aligned}$ & 0.6237 & $* *$ \\
\hline $\begin{aligned} \mathrm{Y}_{2}= & 15.89-0.4762 \mathrm{X}_{4}-0.1583 \mathrm{X}_{6} \\
& -0.1141 \mathrm{X}_{7}+0.0634 \mathrm{X}_{9}\end{aligned}$ & 0.5945 & ** \\
\hline $\mathrm{Y}_{3}=72.65-0.0833 \mathrm{X}_{4}-0.1647 \mathrm{X}_{6}+0.2278 \mathrm{X}_{9}$ & 0.6126 & ** \\
\hline
\end{tabular}

\begin{tabular}{ccc}
\hline Daily intervals & \\
\hline $\mathrm{Y}_{1}=19.78-0.181 \mathrm{X}_{3}-0.069 \mathrm{X}_{4}-0.164 \mathrm{X}_{6}$ & 0.4117 & \\
$-0.182 \mathrm{X}_{7}+0.010 \mathrm{X}_{9}$ & & \\
& & \\
$\mathrm{Y}_{2}=14.96-0.173 \mathrm{X}_{3}-0.075 \mathrm{X}_{4}-0.176 \mathrm{X}_{6}$ & 0.4461 & $* *$ \\
$-0.129 \mathrm{X}_{7}+0.098 \mathrm{X}_{9}$ & & \\
$\mathrm{Y}_{3}=52.36-3.601 \mathrm{X}_{4}-0.2352 \mathrm{X}_{7}+4.511 \mathrm{X}_{9}$ & 0.3587 & ** \\
\hline
\end{tabular}

${ }^{z}$ Where $Y_{1}=$ number of flowers per plant, $Y_{2}=$ number of bolls per plant, $Y_{3}$ $=$ boll retention ratio, $\mathrm{X}_{3}=$ maximum - minimum temperature ${ }^{\circ} \mathrm{C}, \mathrm{X}_{4}=$ evaporation mm.day ${ }^{-1}, \mathrm{X}_{6}=$ surface soil temperature ${ }^{\circ} \mathrm{C}$ at $1800 \mathrm{~h}, \mathrm{X}_{7}=$ sunshine duration $\mathrm{h} \cdot \mathrm{day}^{-1}$, and $\mathrm{X}_{9}=$ minimum relative humidity $\%$. Sawan et al. [12].

The $R^{2}$ values for the 5-day interval were higher than those obtained from daily data for each of the cotton production variables. Also, the 5-day interval gave more efficient and stable estimates than the other studied intervals (data not shown). The $R^{2}$ values for these equations clearly indicate the importance of such equations since the climatic factors involved explained about 59 to $62 \%$ of the variation found in the dependent variables [12].

During the production stage, an accurate weather forecast for the next 10 days would provide an opportunity to avoid any adverse effect for weather factors on cotton production through applying appropriate cultural practices such as adequate irrigation regime or utilization of plant growth regulators. This proposal would be true if the fluctuations in weather conditions were not extreme. Our recommendation would be the accumulation 5-day climatic data, and use this information to select the adequate cultural practices (such as an additional irrigation or utilization of plant growth regulators) that would help circumvent the unfavorable effects of climatic factors. In case of sharp fluctuations in climatic factors, data could be collected daily, and when stability of climatic conditions is restored, the 5-day accumulation of weather data could be used again [12].

\subsection{Response of Flower and Boll Development to Climate Factors before and after Anthesis Day}

The effects of specific climatic factors during both pre- and post-anthesis periods on boll production and retention are mostly unknown. However, by determining the relationship of climatic factors with flower and boll production and retention, the overall level of production can be possibly predicted. Thus, an understanding of these relationships may help physiologists to determine control mechanisms of production in cotton plants [13].

Daily records of the climatic factors (independent variables) were taken for each day during production stage in any season including two additional periods of 15 days before and after the production stage (Table 4). In each season, the data of the dependent and independent variables (68 and 62 days) were regarded as the original file (a file which contains the daily recorded data for any variable during a specific period). Fifteen other files before and another 15 after the production stage were obtained by fixing the dependent variable data, while moving the independent variable data at steps each of 1 day (either before or after production stage) in a matter similar to a sliding role [13]. The following is an example (in the first season):

\begin{tabular}{|c|c|c|c|c|c|c|}
\hline \multirow{3}{*}{ File } & \multicolumn{2}{|c|}{$\begin{array}{l}\text { Data of any } \\
\text { dependent variable } \\
\text { (for each flowers } \\
\text { and bolls) }\end{array}$} & \multicolumn{4}{|c|}{$\begin{array}{l}\text { Any independent variable } \\
\text { (for each climatic factors) }\end{array}$} \\
\hline & \multicolumn{2}{|c|}{ Production stage } & \multicolumn{2}{|c|}{$\begin{array}{l}\text { In case of original } \\
\text { file and files before } \\
\text { production stage }\end{array}$} & \multicolumn{2}{|c|}{$\begin{array}{l}\text { In case of original } \\
\text { file and files after } \\
\text { production stage }\end{array}$} \\
\hline & Date & Days & Date & Days & Date & Days \\
\hline $\begin{array}{l}\text { Original } \\
\text { file }\end{array}$ & $\begin{array}{l}23 \text { Jun- } \\
29 \text { Aug }\end{array}$ & 68 & $\begin{array}{l}23 \text { Jun- } \\
29 \text { Aug }\end{array}$ & 68 & $\begin{array}{l}23 \text { Jun- } \\
29 \text { Aug }\end{array}$ & 68 \\
\hline $\begin{array}{l}1^{\text {st }} \text { new } \\
\text { file }\end{array}$ & $\begin{array}{l}23 \text { Jun- } \\
29 \text { Aug }\end{array}$ & 68 & $\begin{array}{l}22 \text { Jun- } \\
28 \text { Aug }\end{array}$ & 68 & $\begin{array}{l}24 \text { Jun- } \\
30 \text { Aug }\end{array}$ & 68 \\
\hline $\begin{array}{l}2^{\text {nd }} \text { new } \\
\text { file }\end{array}$ & $\begin{array}{l}23 \text { Jun- } \\
29 \text { Aug }\end{array}$ & 68 & $\begin{array}{l}21 \text { Jun- } \\
27 \text { Aug }\end{array}$ & 68 & $\begin{array}{l}25 \text { Jun- } \\
31 \text { Aug }\end{array}$ & 68 \\
\hline $\begin{array}{l}15^{\text {th }} \text { new } \\
\text { file }\end{array}$ & $\begin{array}{l}23 \text { Jun- } \\
29 \text { Aug }\end{array}$ & 68 & $\begin{array}{l}8 \text { Jun- } \\
14 \text { Aug }\end{array}$ & 68 & $\begin{array}{l}8 \mathrm{Jul}- \\
13 \mathrm{Sept}\end{array}$ & 68 \\
\hline
\end{tabular}

Thus, the climate data were organized into records according to the complete production stage (68 days the first year and 62 days the second year) and 15 days, 14 days, 13 days... and 1 day periods both before and after the production stage. This produced 31 climate periods per year that were analyzed for their relationships with cotton flowering and boll production [13].

Simple correlation coefficients were computed between the original dependent variable (boll setting and boll retention) and the independent variables for each of the original file and the 15 new files just before or after flowering in each season. The significance of the simple correlation at a probability level not exceeding $5 \%$ was tested to determine the factors affecting the dependent 
Table 4. Mean, standard deviation, maximum and minimum values of the climatic factors during the flower and boll stage (initial time) and the 15 days prior to flowering or subsequent to boll setting for I and II season at Giza, Egypt.

\begin{tabular}{|c|c|c|c|c|c|c|c|c|}
\hline \multirow{2}{*}{ Climatic factors } & \multicolumn{4}{|c|}{ First season ${ }^{*}$} & \multicolumn{4}{|c|}{ Second season ${ }^{* *}$} \\
\hline & Mean & S.D ${ }^{\mathrm{a}}$ & $\operatorname{Max}^{b}$ & $\operatorname{Min}^{\mathrm{c}}$ & Mean & S.D. & Max & Min \\
\hline Min temp $\left[{ }^{\circ} \mathrm{C}\right]\left(\mathrm{X}_{2}\right)$ & 21.5 & 1.0 & 24.5 & 18.6 & 21.4 & 0.9 & 24.3 & 18.4 \\
\hline Max-Min temp $\left[{ }^{\circ} \mathrm{C}\right]\left(\mathrm{X}_{3}\right)^{\star}$ & 12.6 & 1.1 & 20.9 & 9.4 & 12.4 & 1.3 & 17.6 & 8.5 \\
\hline Evapor $\left[\mathrm{mm} \cdot \mathrm{d}^{-1}\right]\left(\mathrm{X}_{4}\right)$ & 10.6 & 1.6 & 16.4 & 7.6 & 6.0 & 0.7 & 9.8 & 4.1 \\
\hline $600 \mathrm{~h}$ temp $\left[{ }^{\circ} \mathrm{C}\right]\left(\mathrm{X}_{5}\right)$ & 17.5 & 1.1 & 21.5 & 13.9 & 17.6 & 1.2 & 22.4 & 13.3 \\
\hline $1800 \mathrm{~h}$ temp $\left[{ }^{\circ} \mathrm{C}\right]\left(\mathrm{X}_{6}\right)$ & 24.2 & 1.9 & 32.3 & 19.6 & 23.7 & 1.1 & 27.4 & 20.6 \\
\hline Sunshine $\left[\mathrm{h} \cdot \mathrm{d}^{-1}\right]\left(\mathrm{X}_{7}\right)$ & 11.7 & 0.8 & 12.9 & 9.9 & 11.7 & 0.4 & 13.0 & 10.3 \\
\hline Max hum [\%] $\left(\mathrm{X}_{8}\right)$ & 85.6 & 3.3 & 96.0 & 62.0 & 72.9 & 3.8 & 84.0 & 51.0 \\
\hline Min hum $[\%]\left(\mathrm{X}_{9}\right)$ & 30.2 & 5.2 & 45.0 & 11.0 & 39.1 & 5.0 & 52.0 & 23.0 \\
\hline Wind speed $\left[\mathrm{m} \cdot \mathrm{s}^{-1}\right]\left(\mathrm{X}_{10}\right)$ & ND & ND & ND & ND & 4.6 & 0.9 & 7.8 & 2.2 \\
\hline
\end{tabular}

${ }^{*}$ Flower and boll stage (68 days, from 23 June through 29 August). ${ }^{* *}$ Flower and boll stage (62 days, from 29 June through 29 August). ${ }^{*}$ Diurnal temperature range. ${ }^{\mathrm{a}}$ Standard deviation. ${ }^{\mathrm{b}}$ Maxmum. ${ }^{\mathrm{c}}$ Minimum. ND not determined. Sawan et al. [13].

variables. The relationship between the most effective and consistent climatic factors affecting flower and boll production and retention was computed using the stepwise regression analysis method. Linear regression equations comprising selected predictive variables were computed and coefficients of determination $\left(r^{2}\right.$ for simple or $R^{2}$ for multiple linear regression equations) were calculated to measure the efficiency of the regression models in explaining the variation in the data. The statistical analysis was carried out according to Draper and Smith [17], by means of the computer program SAS package using the procedures outlined in the general linear model (GLM) [15].

\subsubsection{Correlation Estimates}

1) Results of the correlation between climatic factors and each of flower and boll production during the 15 days periods before flowering day (Tables 5 and 6) revealed the following [13]:

\section{First Season}

Daily evaporation and sunshine duration showed consistent negative and statistically significant correlations with both flower and boll production for each of the 15 moving window periods before anthesis (Table 5). Evaporation appeared to be the most important climate factor affecting flower and boll production. Daily maximum and minimum humidity showed consistent positive and statistically significant correlations with both flower and boll production in most of the 15 moving window periods before anthesis (Table 5). Maximum daily temperature showed low but significant negative correlation with flower production during the $2-5,8$, and 10 days periods before anthesis. Minimum daily temperatures generally showed insignificant correlation with both production variables. The diurnal temperature range showed few correlations with flower and boll production. Daily soil surface temperature at $600 \mathrm{~h}$ showed a significant positive correlation with boll production during the pe- riod extending from the 11 - 15 days period before anthesis, while its effect on flowering was confined only to the 12 and the 15 days periods prior anthesis. Daily soil surface temperature at $1800 \mathrm{~h}$ showed a significant negative correlation with flower production during the 2 - 10 days periods before anthesis [13].

\section{Second Season}

Daily Evaporation, the diurnal temperature range, and sunshine duration were negatively and significantly correlated with both flower and boll production in all the 15 days periods, while maximum daily temperature was negatively and significantly related to flower and boll formation during the 2 - 5 days periods before anthesis (Table 6) [13].

Minimum daily temperature showed positive and statistically significant correlations with both production variables only during the 9 - 15 days periods before anthesis, while daily minimum humidity showed the same correlation trend in all the 15 moving window periods before anthesis. Daily soil surface temperature at $600 \mathrm{~h}$ was positively and significantly correlated with flower and boll production for the 12,14, and 15 days periods prior to anthesis only. Daily soil surface temperature at $1800 \mathrm{~h}$ showed negative and significant correlations with both production variables only during the first and second days periods before flowering. Daily maximum humidity showed insignificant correlation with both flower and boll production except for one day period only (the $15^{\text {th }}$ day). Generally, the results in the two seasons indicated that daily evaporation, sunshine duration and minimum humidity were the most effective and consistent climatic factors, which exhibited significant relationships with the production variables for all the 15 days periods before anthesis in both seasons [13].

The factors in this study which had been found to be associated with boll development are the climatic factors that would influence water loss between plant and atmosphere (low evaporation demand, high humidity, and 
Table 5. Simple correlation coefficients $(r)$ between climatic factors and number of flower and harvested bolls in initial time $(0)$ and each of the 15-day periods before flowering in the first season (I).

\begin{tabular}{|c|c|c|c|c|c|c|c|c|c|c|}
\hline \multirow{3}{*}{ Climate period } & & \multicolumn{3}{|c|}{ Air temp $\left({ }^{\circ} \mathrm{C}\right)$} & \multirow{2}{*}{$\underset{\left(\mathrm{mm} \cdot \mathrm{d}^{-1}\right)}{\text { Evap }}$} & \multicolumn{2}{|c|}{ Surface soil temp $\left({ }^{\circ} \mathrm{C}\right)$} & \multirow{2}{*}{$\begin{array}{l}\text { Sunshine } \\
\text { duration } \\
\left(\mathrm{h} \cdot \mathrm{d}^{-1}\right)\end{array}$} & \multicolumn{2}{|c|}{ Humidity (\%) } \\
\hline & & $\operatorname{Max}^{\mathrm{a}}$ & $\operatorname{Min}^{\mathrm{b}}$ & Max-Min & & $600 \mathrm{~h}$ & $1800 \mathrm{~h}$ & & Max & Min \\
\hline & & $\left(\mathrm{X}_{1}\right)$ & $\left(\mathrm{X}_{2}\right)$ & $\left(\mathrm{X}_{3}\right)$ & $\left(\mathrm{X}_{4}\right)$ & $\left(\mathrm{X}_{5}\right)$ & $\left(\mathrm{X}_{6}\right)$ & $\left(\mathrm{X}_{7}\right)$ & $\left(\mathrm{X}_{8}\right)$ & $\left(\mathrm{X}_{9}\right)$ \\
\hline \multirow{2}{*}{$0^{\#}$} & Flower & -0.07 & -0.06 & -0.03 & $-0.56^{* *}$ & -0.01 & -0.20 & $-0.25^{*}$ & $0.40^{* *}$ & 0.14 \\
\hline & Boll & -0.03 & -0.07 & -0.01 & $-0.53^{* *}$ & -0.06 & -0.16 & -0.14 & $0.37^{* *}$ & 0.10 \\
\hline \multirow{2}{*}{1} & Flower & -0.15 & -0.08 & -0.11 & $-0.64^{* *}$ & -0.01 & -0.17 & $-0.30^{*}$ & $0.39^{* *}$ & 0.20 \\
\hline & Boll & -0.07 & -0.08 & -0.02 & $-0.58^{* *}$ & -0.06 & -0.10 & $-0.23^{*}$ & $0.36^{* *}$ & 0.13 \\
\hline \multirow{2}{*}{2} & Flower & $-0.26^{*}$ & -0.10 & -0.22 & $-0.69^{* *}$ & -0.07 & $-0.30^{*}$ & $-0.35^{* *}$ & $0.42^{* *}$ & $0.30^{*}$ \\
\hline & Boll & -0.18 & -0.08 & -0.14 & $-0.64^{* *}$ & -0.05 & -0.21 & $-0.25^{*}$ & $0.40^{* *}$ & 0.20 \\
\hline \multirow{2}{*}{3} & Flower & $-0.28^{*}$ & -0.02 & $-0.31^{* *}$ & $-0.72^{* *}$ & 0.15 & $-0.29^{*}$ & $-0.37^{* *}$ & $0.46^{* *}$ & $0.35^{* *}$ \\
\hline & Boll & -0.19 & -0.02 & -0.21 & $-0.65^{* *}$ & 0.11 & -0.20 & $-0.30^{*}$ & $0.37^{* *}$ & $0.25^{*}$ \\
\hline \multirow[b]{2}{*}{4} & Flower & $-0.26^{*}$ & -0.03 & $-0.26^{*}$ & $-0.67^{* *}$ & 0.08 & $-0.24^{*}$ & $-0.41^{* *}$ & $0.46^{* *}$ & $0.35^{* *}$ \\
\hline & Boll & -0.21 & -0.04 & -0.21 & $-0.63^{* *}$ & 0.04 & -0.18 & $-0.35^{* *}$ & $0.39^{* *}$ & $0.29^{*}$ \\
\hline \multirow{2}{*}{5} & Flower & $-0.27^{*}$ & -0.02 & $-0.27^{*}$ & $-0.68^{* *}$ & 0.16 & $-0.29^{*}$ & $-0.45^{* *}$ & $0.49^{* *}$ & $0.38^{* *}$ \\
\hline & Boll & -0.22 & 0.00 & $-0.24^{*}$ & $-0.63^{* *}$ & 0.16 & -0.21 & $-0.39^{* *}$ & $0.44^{* *}$ & $0.32^{* *}$ \\
\hline \multirow{2}{*}{6} & Flower & -0.21 & 0.05 & $-0.25^{*}$ & $-0.73^{* *}$ & 0.16 & $-0.28^{*}$ & $-0.46^{* *}$ & $0.47^{* *}$ & $0.42^{* *}$ \\
\hline & Boll & -0.15 & 0.08 & -0.21 & $-0.67^{* *}$ & 0.19 & -0.19 & $-0.46^{* *}$ & $0.43^{* *}$ & $0.35^{* *}$ \\
\hline \multirow{2}{*}{7} & Flower & -0.17 & -0.01 & -0.17 & $-0.69^{* *}$ & 0.10 & $-0.27^{*}$ & $-0.43^{* *}$ & $0.46^{* *}$ & $0.35^{* *}$ \\
\hline & Boll & -0.11 & -0.06 & -0.15 & $-0.64^{* *}$ & 0.14 & -0.19 & $-0.46^{* *}$ & $0.43^{* *}$ & $0.32^{* *}$ \\
\hline \multirow{2}{*}{8} & Flower & $-0.24^{*}$ & -0.03 & $-0.24^{*}$ & $-0.71^{* *}$ & 0.09 & $-0.30^{*}$ & $-0.44^{* *}$ & $0.45^{* *}$ & $0.45^{* *}$ \\
\hline & Boll & -0.14 & 0.04 & -0.17 & $-0.63^{* *}$ & 0.16 & -0.17 & $-0.48^{* *}$ & $0.44^{* *}$ & $0.39^{* *}$ \\
\hline \multirow{2}{*}{9} & Flower & -0.23 & -0.10 & -0.19 & $-0.68^{* *}$ & 0.05 & $-0.33^{* *}$ & $-0.32^{* *}$ & $0.43^{* *}$ & $0.44^{* *}$ \\
\hline & Boll & -0.14 & 0.04 & -0.17 & $-0.61^{* *}$ & 0.15 & -0.21 & $-0.40^{* *}$ & $0.42^{* *}$ & $0.41^{* *}$ \\
\hline \multirow{2}{*}{10} & Flower & $-0.26^{*}$ & 0.05 & $-0.30^{*}$ & $-0.67^{* *}$ & 0.13 & $-0.29^{*}$ & $-0.29^{*}$ & $0.40^{* *}$ & $0.48^{* *}$ \\
\hline & Boll & -0.14 & 0.13 & -0.22 & $-0.58^{* *}$ & 0.22 & -0.17 & $-0.36^{* *}$ & $0.46^{* *}$ & $0.41^{* *}$ \\
\hline \multirow{2}{*}{11} & Flower & -0.20 & 0.10 & $-0.27^{*}$ & $-0.62^{* *}$ & 0.21 & -0.19 & $-0.29^{*}$ & $0.42^{* *}$ & $0.44^{* *}$ \\
\hline & Boll & -0.04 & 0.22 & -0.16 & $-0.53^{* *}$ & $0.27^{*}$ & -0.04 & $-0.38^{* *}$ & $0.45^{* *}$ & $0.36^{* *}$ \\
\hline \multirow{2}{*}{12} & Flower & -0.17 & 0.16 & $-0.26^{*}$ & $-0.62^{* *}$ & $0.29^{*}$ & -0.15 & $-0.40^{* *}$ & $0.44^{* *}$ & $0.45^{* *}$ \\
\hline & Boll & 0.00 & $0.25^{*}$ & -0.13 & $-0.51^{* *}$ & $0.35^{* *}$ & -0.04 & $-0.45^{* *}$ & $0.40^{* *}$ & $0.30^{*}$ \\
\hline \multirow{2}{*}{13} & Flower & -0.13 & 0.16 & -0.22 & $-0.62^{* *}$ & 0.23 & -0.12 & $-0.42^{* *}$ & $0.43^{* *}$ & $0.45^{* *}$ \\
\hline & Boll & 0.00 & 0.22 & -0.11 & $-0.51^{* *}$ & $0.30^{*}$ & -0.03 & $-0.49^{* *}$ & $0.41^{* *}$ & $0.33^{* *}$ \\
\hline \multirow{2}{*}{14} & Flower & -0.08 & 0.18 & -0.18 & $-0.56^{* *}$ & 0.21 & -0.15 & $-0.44^{* *}$ & $0.41^{* *}$ & $0.46^{* *}$ \\
\hline & Boll & 0.01 & 0.21 & -0.10 & $-0.47^{* *}$ & $0.26^{*}$ & -0.09 & $-0.49^{* *}$ & $0.42^{* *}$ & $0.33^{* *}$ \\
\hline \multirow{2}{*}{15} & Flower & -0.08 & 0.22 & -0.21 & $-0.51^{* *}$ & $0.24^{*}$ & -0.22 & $-0.42^{* *}$ & $0.39^{* *}$ & $0.38^{* *}$ \\
\hline & Boll & -0.03 & 0.19 & -0.13 & $-0.45^{* *}$ & $0.24^{*}$ & -0.17 & $-0.44^{* *}$ & $0.43^{* *}$ & $0.30^{*}$ \\
\hline
\end{tabular}

"Significant at $5 \%$ level and ${ }^{* *}$ significant at $1 \%$ level. ${ }^{\#} 0=$ Initial time. ${ }^{\circ}$ Diurnal temperature range. ${ }^{\mathrm{a}}$ Maxmum. ${ }^{\mathrm{b}}$ Minimum. Sawan et al. [13].

shorter solar duration). This can lead to direct effects on the fruiting forms themselves and inhibitory effects on mid-afternoon photosynthetic rates even under well-watered conditions. Human et al. [22] stated that, when sunflower plants were grown under controlled temperature regimes, water stress during budding, anthesis and seed filling, the $\mathrm{CO}_{2}$ uptake rate per unit leaf area as well as total uptake rate per plant, significantly diminished with stress, while this effect resulted in a significant decrease in yield per plant.
2) The correlation between climatic factors and each of boll production and boll retention over a period of 15 days periods after flowering (boll setting) day (Tables 7 and 8) [13] revealed the following:

First Season

Daily evaporation showed significant negative correlation with number of bolls for all the 15 days periods after flowering (Table 7). Meanwhile its relationship with retention ratio was positive and significant in the 9 15 days periods after flowering. Daily sunshine duration 
Table 6. Simple correlation coefficients $(r)$ between climatic factors ${ }^{\mathrm{z}}$ and number of flower and harvested bolls in initial time $(0)$ and each of the 15-day periods before flowering in the second season (II).

\begin{tabular}{|c|c|c|c|c|c|c|c|c|c|c|}
\hline \multirow{3}{*}{ Climate period } & & \multicolumn{3}{|c|}{ Air temp $\left({ }^{\circ} \mathrm{C}\right)$} & \multirow{2}{*}{$\begin{array}{c}\text { Evap } \\
\left(\mathrm{mm}^{-1} \mathrm{~d}^{-1}\right)\end{array}$} & \multicolumn{2}{|c|}{ Surface soil temp $\left({ }^{\circ} \mathrm{C}\right)$} & \multirow{2}{*}{$\begin{array}{l}\text { Sunshine } \\
\text { duration } \\
\left(\mathrm{h} \cdot \mathrm{d}^{-1}\right)\end{array}$} & \multicolumn{2}{|c|}{ Humidity (\%) } \\
\hline & & Max & Min & Max-Min` & & $600 \mathrm{~h}$ & $1800 \mathrm{~h}$ & & Max & Min \\
\hline & & $\left(\mathrm{X}_{1}\right)$ & $\left(\mathrm{X}_{2}\right)$ & $\left(\mathrm{X}_{3}\right)$ & $\left(\mathrm{X}_{4}\right)$ & $\left(\mathrm{X}_{5}\right)$ & $\left(\mathrm{X}_{6}\right)$ & $\left(\mathrm{X}_{7}\right)$ & $\left(\mathrm{X}_{8}\right)$ & $\left(\mathrm{X}_{9}\right)$ \\
\hline \multirow{2}{*}{$0^{\#}$} & Flower & $-0.42^{* *}$ & 0.00 & $-0.36^{* *}$ & $-0.61^{* *}$ & -0.14 & $-0.37^{* *}$ & $-0.37^{* *}$ & 0.01 & $0.45^{* *}$ \\
\hline & Boll & $-0.42^{* *}$ & 0.02 & $-0.37^{* *}$ & $-0.59^{* *}$ & -0.13 & $-0.36^{* *}$ & $-0.36^{* *}$ & 0.01 & $0.46^{* *}$ \\
\hline \multirow{2}{*}{1} & Flower & $-0.42^{* *}$ & 0.10 & $-0.42^{* *}$ & $-0.63^{* *}$ & -0.08 & $-0.29^{*}$ & $-0.41^{* *}$ & 0.05 & $0.48^{* *}$ \\
\hline & Boll & $-0.41^{* *}$ & 0.11 & $-0.42^{* *}$ & $-0.62^{* *}$ & -0.07 & $-0.28^{*}$ & $-0.41^{* *}$ & 0.05 & $0.47^{* *}$ \\
\hline \multirow{2}{*}{2} & Flower & $-0.40^{* *}$ & 0.08 & $-0.43^{* *}$ & $-0.65^{* *}$ & -0.09 & $-0.27^{*}$ & $-0.39^{* *}$ & 0.02 & $0.49^{* *}$ \\
\hline & Boll & $-0.40^{* *}$ & 0.08 & $-0.43^{* *}$ & $-0.64^{* *}$ & -0.08 & $-0.26^{*}$ & $-0.40^{* *}$ & 0.03 & $0.49^{* *}$ \\
\hline \multirow{2}{*}{3} & Flower & $-0.38^{* * *}$ & 0.13 & $-0.43^{* *}$ & $-0.61^{* *}$ & -0.06 & -0.17 & $-0.38^{* *}$ & 0.00 & $0.45^{* *}$ \\
\hline & Boll & $-0.37^{* *}$ & 0.15 & $-0.44^{* *}$ & $-0.61^{* *}$ & -0.05 & -0.15 & $-0.38^{* *}$ & 0.01 & $0.46^{* *}$ \\
\hline \multirow{2}{*}{4} & Flower & $-0.36^{* *}$ & 0.17 & $-0.41^{* *}$ & $-0.61^{* *}$ & -0.04 & -0.18 & $-0.38^{* *}$ & 0.02 & $0.45^{* * *}$ \\
\hline & Boll & $-0.35^{* *}$ & 0.18 & $-0.41^{* *}$ & $-0.60^{* *}$ & -0.03 & -0.16 & $-0.36^{* *}$ & 0.03 & $0.44^{* *}$ \\
\hline \multirow{2}{*}{5} & Flower & $-0.30^{*}$ & 0.13 & $-0.36^{* *}$ & $-0.60^{* * *}$ & -0.07 & -0.23 & $-0.32^{* *}$ & -0.05 & $0.43^{* * *}$ \\
\hline & Boll & $-0.28^{*}$ & 0.15 & $-0.35^{* *}$ & $-0.58^{* *}$ & -0.05 & -0.21 & $-0.31^{* *}$ & -0.05 & $0.41^{* *}$ \\
\hline \multirow{2}{*}{6} & Flower & -0.24 & 0.21 & $-0.38^{* *}$ & $-0.61^{* *}$ & -0.02 & -0.12 & $-0.28^{*}$ & 0.02 & $0.40^{* *}$ \\
\hline & Boll & -0.22 & 0.24 & $-0.38^{* *}$ & $-0.59^{* *}$ & 0.00 & -0.07 & $-0.29^{*}$ & 0.02 & $0.40^{* *}$ \\
\hline \multirow{2}{*}{7} & Flower & -0.19 & 0.23 & $-0.29^{*}$ & $-0.54^{* *}$ & -0.03 & -0.05 & $-0.26^{*}$ & -0.04 & $0.32^{* *}$ \\
\hline & Boll & -0.18 & 0.23 & $-0.27^{*}$ & $-0.53^{* *}$ & -0.02 & -0.03 & $-0.27^{*}$ & -0.04 & $0.30^{*}$ \\
\hline \multirow{2}{*}{8} & Flower & -0.15 & 0.24 & $-0.25^{*}$ & $-0.52^{* *}$ & -0.03 & -0.07 & $-0.24^{*}$ & -0.05 & $0.28^{*}$ \\
\hline & Boll & -0.14 & 0.22 & -0.22 & $-0.51^{* *}$ & -0.03 & -0.06 & $-0.22^{*}$ & -0.05 & $0.26^{*}$ \\
\hline \multirow{2}{*}{9} & Flower & -0.16 & $0.34^{* * *}$ & $-0.32^{* *}$ & $-0.56^{* *}$ & 0.08 & -0.02 & $-0.25^{*}$ & 0.05 & $0.30^{*}$ \\
\hline & Boll & -0.14 & $0.34^{* *}$ & $-0.31^{* *}$ & $-0.56^{* *}$ & 0.09 & -0.01 & $-0.23^{*}$ & 0.07 & $0.29^{*}$ \\
\hline \multirow{2}{*}{10} & Flower & -0.16 & $0.31^{* *}$ & $-0.30^{*}$ & $-0.56^{* *}$ & 0.11 & -0.06 & $-0.27^{*}$ & 0.11 & $0.33^{* *}$ \\
\hline & Boll & -0.14 & $0.28^{*}$ & $-0.27^{*}$ & $-0.55^{* *}$ & 0.09 & -0.07 & $-0.25^{*}$ & 0.09 & $0.31^{* *}$ \\
\hline \multirow{2}{*}{11} & Flower & -0.16 & $0.31^{* *}$ & $-0.27^{*}$ & $-0.55^{* *}$ & 0.10 & -0.02 & $-0.31^{* *}$ & 0.08 & $0.32^{* *}$ \\
\hline & Boll & -0.15 & $0.29^{*}$ & $-0.26^{*}$ & $-0.53^{* *}$ & 0.10 & 0.00 & $-0.29^{*}$ & 0.08 & $0.29^{*}$ \\
\hline \multirow{2}{*}{12} & Flower & -0.17 & $0.44^{* *}$ & $-0.37^{* *}$ & $-0.57^{* *}$ & $0.26^{*}$ & 0.02 & $-0.36^{* *}$ & 0.17 & $0.34^{* *}$ \\
\hline & Boll & -0.17 & $0.42^{* *}$ & $-0.36^{* *}$ & $-0.55^{* *}$ & $0.25^{*}$ & 0.01 & $-0.34^{* *}$ & 0.16 & $0.32^{* *}$ \\
\hline \multirow{2}{*}{13} & Flower & -0.14 & $0.40^{* * *}$ & $-0.33^{* *}$ & $-0.56^{* *}$ & 0.21 & 0.03 & $-0.28^{*}$ & 0.10 & $0.34^{* *}$ \\
\hline & Boll & -0.15 & $0.38^{* *}$ & $-0.34^{* *}$ & $-0.56^{* *}$ & 0.21 & 0.01 & $-0.27^{*}$ & 0.09 & $0.33^{* *}$ \\
\hline \multirow{2}{*}{14} & Flower & -0.19 & $0.39^{* *}$ & $-0.38^{* *}$ & $-0.59^{* *}$ & $0.25^{*}$ & 0.04 & $-0.34^{* *}$ & 0.16 & $0.35^{* *}$ \\
\hline & Boll & -0.20 & $0.39^{* *}$ & $-0.40^{* *}$ & $-0.59^{* *}$ & $0.26^{*}$ & 0.03 & $-0.36^{* *}$ & 0.17 & $0.36^{* *}$ \\
\hline \multirow{2}{*}{15} & Flower & -0.24 & $0.49^{* *}$ & $-0.45^{* *}$ & $-0.62^{* *}$ & $0.37^{* *}$ & 0.16 & $-0.38^{* *}$ & $0.27^{*}$ & $0.42^{* *}$ \\
\hline & Boll & -0.24 & $0.51^{* *}$ & $-0.48^{* *}$ & $-0.63^{* *}$ & $0.40^{* *}$ & 0.15 & $-0.40^{* *}$ & $0.26^{*}$ & $0.43^{* *}$ \\
\hline
\end{tabular}

"Significant at $5 \%$ level and ${ }^{* *}$ significant at $1 \%$ level. ${ }^{*} 0=$ Initial time. ${ }^{*}$ Diurnal temperature range. ${ }^{2}$ Wind speed did not show significant effect upon the studied production variables, so it is not reported. Sawan et al. [13].

was positively and significantly correlated with boll retention ratio during the $5-13$ days periods after flowering. Daily maximum humidity had a significant positive correlation with the number of bolls during the first 8 days periods after flowering, while daily minimum humidity had the same correlation for only the 11 , and 12 days periods after flowering. Daily maximum and minimum temperatures and the diurnal temperature range, as well as soil surface temperature at 1800 did not show significant relationships with both number of bolls and retention ratio. Daily soil surface temperature at $600 \mathrm{~h}$ had a significant negative correlation with boll retention ratio during the $3-7$ days periods after anthesis [13].

\section{Second Season}

Daily evaporation, soil surface temperature at $1800 \mathrm{~h}$, and sunshine duration had a significant negative correlation with number of bolls in all the 15 days periods after anthesis (Table 8). Daily maximum and minimum tem- 
Table 7. Simple correlation coefficient $(r)$ values between climatic factors and number of harvested bolls and retention ratio in initial time $(0)$ and each of the 15-day periods after flowering in the first season (I).

\begin{tabular}{|c|c|c|c|c|c|c|c|c|c|c|}
\hline \multirow{3}{*}{$\begin{array}{l}\text { Climate } \\
\text { period }\end{array}$} & & \multicolumn{3}{|c|}{ Air temp $\left({ }^{\circ} \mathrm{C}\right)$} & \multirow{2}{*}{$\underset{\left(\mathrm{mm} \cdot \mathrm{d}^{-1}\right)}{\text { Evap }}$} & \multicolumn{2}{|c|}{ Surface soil temp $\left({ }^{\circ} \mathrm{C}\right)$} & \multirow{2}{*}{$\begin{array}{l}\text { Sunshine } \\
\text { duration } \\
\left(\mathrm{h} \cdot \mathrm{d}^{-1}\right)\end{array}$} & \multicolumn{2}{|c|}{ Humidity (\%) } \\
\hline & & $\operatorname{Max}$ & Min & Max-Min` & & $600 \mathrm{~h}$ & $1800 \mathrm{~h}$ & & Max & Min \\
\hline & & $\left(\mathrm{X}_{1}\right)$ & $\left(\mathrm{X}_{2}\right)$ & $\left(\mathrm{X}_{3}\right)$ & $\left(\mathrm{X}_{4}\right)$ & $\left(\mathrm{X}_{5}\right)$ & $\left(\mathrm{X}_{6}\right)$ & $\left(\mathrm{X}_{7}\right)$ & $\left(\mathrm{X}_{8}\right)$ & $\left(\mathrm{X}_{9}\right)$ \\
\hline \multirow{2}{*}{$0^{\#}$} & Retention ratio ${ }^{\circ}$ & -0.05 & -0.03 & -0.03 & -0.10 & -0.11 & 0.10 & 0.20 & -0.04 & -0.02 \\
\hline & No. of bolls & -0.03 & -0.07 & -0.01 & $-0.53^{* *}$ & -0.06 & -0.16 & -0.14 & $0.37^{* *}$ & 0.10 \\
\hline \multirow{2}{*}{1} & Retention ratio & -0.07 & -0.08 & -0.01 & -0.10 & -0.16 & 0.04 & 0.15 & 0.04 & 0.05 \\
\hline & No. of bolls & 0.02 & -0.08 & 0.08 & $-0.49^{* *}$ & -0.09 & -0.05 & -0.20 & $0.35^{* *}$ & 0.09 \\
\hline \multirow{2}{*}{2} & Retention ratio & -0.08 & -0.14 & 0.02 & -0.08 & -0.19 & 0.03 & 0.17 & 0.02 & -0.02 \\
\hline & No. of bolls & 0.02 & -0.04 & 0.07 & $-0.46^{* *}$ & -0.06 & -0.01 & -0.19 & $0.33^{* *}$ & 0.09 \\
\hline \multirow{2}{*}{3} & Retention ratio & -0.09 & -0.21 & 0.06 & -0.08 & $-0.24^{*}$ & 0.02 & 0.19 & 0.01 & -0.10 \\
\hline & No. of bolls & 0.03 & -0.03 & 0.06 & $-0.44^{* *}$ & -0.04 & 0.05 & -0.18 & $0.32^{* *}$ & 0.08 \\
\hline \multirow{2}{*}{4} & Retention ratio & -0.05 & -0.20 & 0.09 & -0.01 & $-0.24^{*}$ & 0.01 & 0.22 & 0.00 & -0.15 \\
\hline & No. of bolls & 0.01 & -0.05 & 0.05 & $-0.40^{* *}$ & -0.03 & 0.04 & -0.16 & $0.31^{*}$ & 0.08 \\
\hline \multirow{2}{*}{5} & Retention ratio & -0.03 & -0.21 & 0.13 & 0.07 & $-0.25^{*}$ & 0.00 & $0.26^{*}$ & -0.02 & -0.22 \\
\hline & No. of bolls & 0.00 & -0.07 & 0.05 & $-0.37^{* *}$ & -0.02 & 0.03 & -0.13 & $0.29^{*}$ & 0.07 \\
\hline \multirow[b]{2}{*}{6} & Retention ratio & 0.01 & -0.19 & 0.15 & 0.12 & $-0.24^{*}$ & 0.02 & $0.27^{*}$ & -0.03 & -0.20 \\
\hline & No. of bolls & -0.01 & -0.08 & 0.04 & $-0.38^{* *}$ & -0.02 & 0.04 & -0.15 & $0.31^{*}$ & 0.13 \\
\hline \multirow{2}{*}{7} & Retention ratio & 0.05 & -0.17 & 0.17 & 0.18 & $-0.25^{*}$ & 0.05 & $0.29^{*}$ & -0.02 & -0.21 \\
\hline & No. of bolls & -0.03 & -0.09 & 0.03 & $-0.39^{* *}$ & -0.04 & 0.06 & -0.14 & $0.34^{* *}$ & 0.18 \\
\hline \multirow{2}{*}{8} & Retention ratio & 0.06 & -0.08 & 0.13 & 0.21 & -0.20 & 0.07 & $0.28^{*}$ & -0.06 & -0.19 \\
\hline & No. of bolls & -0.05 & -0.07 & -0.01 & $-0.35^{* *}$ & -0.02 & 0.02 & -0.17 & $0.28^{*}$ & 0.17 \\
\hline \multirow{2}{*}{9} & Retention ratio & 0.08 & 0.00 & 0.08 & $0.26^{*}$ & -0.14 & 0.08 & $0.29^{*}$ & -0.12 & -0.20 \\
\hline & No. of bolls & -0.08 & -0.06 & -0.05 & $-0.33^{* *}$ & -0.01 & 0.00 & -0.23 & 0.20 & 0.16 \\
\hline \multirow{2}{*}{10} & Retention ratio & 0.06 & -0.02 & 0.05 & $0.27^{*}$ & -0.13 & 0.09 & $0.27^{*}$ & -0.10 & -0.08 \\
\hline & No. of bolls & -0.11 & -0.10 & -0.07 & $-0.34^{* *}$ & -0.03 & -0.03 & -0.19 & 0.18 & 0.21 \\
\hline \multirow{2}{*}{11} & Retention ratio & 0.04 & -0.04 & 0.08 & $0.28^{*}$ & -0.12 & 0.08 & $0.26^{*}$ & -0.09 & -0.05 \\
\hline & No. of bolls & -0.18 & -0.18 & -0.06 & $-0.37^{* *}$ & -0.10 & -0.04 & -0.14 & 0.15 & $0.28^{*}$ \\
\hline \multirow{2}{*}{12} & Retention ratio & 0.02 & 0.01 & -0.08 & $0.32^{* *}$ & -0.05 & 0.05 & $0.25^{*}$ & -0.08 & -0.03 \\
\hline & No. of bolls & -0.17 & -0.13 & -0.08 & $-0.32^{* *}$ & -0.06 & -0.07 & -0.11 & 0.16 & $0.24^{*}$ \\
\hline \multirow{2}{*}{13} & Retention ratio & -0.04 & 0.04 & -0.09 & $0.38^{* *}$ & 0.00 & 0.01 & $0.27^{*}$ & -0.09 & -0.02 \\
\hline & No. of bolls & -0.15 & -0.09 & -0.09 & $-0.29^{*}$ & -0.03 & -0.10 & -0.08 & 0.18 & 0.20 \\
\hline \multirow{2}{*}{14} & Retention ratio & -0.07 & 0.04 & -0.13 & $0.34^{* *}$ & 0.06 & -0.02 & 0.18 & -0.08 & -0.01 \\
\hline & No. of bolls & -0.15 & -0.10 & -0.10 & $-0.28^{*}$ & -0.01 & -0.10 & -0.15 & 0.17 & 0.17 \\
\hline \multirow{2}{*}{15} & Retention ratio & -0.13 & 0.03 & -0.18 & $0.33^{* *}$ & 0.09 & -0.04 & 0.06 & -0.07 & 0.00 \\
\hline & No. of bolls & -0.16 & -0.10 & -0.11 & $-0.28^{*}$ & 0.00 & -0.11 & -0.13 & 0.17 & 0.15 \\
\hline
\end{tabular}

${ }^{*}$ and ${ }^{* *}$ Significant at $5 \%$ and $1 \%$ levels of significance, respectively. ${ }^{*} 0=$ Initial time. Retention ratio: (the number of retained bolls obtained from the total number of each daily tagged flowers in all selected plants at harvest/each daily number of tagged flowers in all selected plants) $\times 100$. ${ }^{\star D i u r n a l}$ temperature range. Sawan et al. [13]. 
Table 8. Simple correlation coefficient $(r)$ values between climatic factors ${ }^{\mathrm{z}}$ and number of harvested bolls and retention ratio in initial time (0) and each of the 15-day periods after flowering in the second season (II).

\begin{tabular}{|c|c|c|c|c|c|c|c|c|c|c|}
\hline \multirow{3}{*}{$\begin{array}{l}\text { Climate } \\
\text { period }\end{array}$} & & \multicolumn{3}{|c|}{ Air temp $\left({ }^{\circ} \mathrm{C}\right)$} & \multirow{2}{*}{$\underset{\left(\mathrm{mm} \cdot \mathrm{d}^{-1}\right)}{\text { Evap }}$} & \multicolumn{2}{|c|}{ Surface soil temp $\left({ }^{\circ} \mathrm{C}\right)$} & \multirow{2}{*}{$\begin{array}{l}\text { Sunshine } \\
\text { duration } \\
\left(\mathrm{h} \cdot \mathrm{d}^{-1}\right)\end{array}$} & \multicolumn{2}{|c|}{ Humidity (\%) } \\
\hline & & Max & Min & Max-Min` & & $600 \mathrm{~h}$ & $1800 \mathrm{~h}$ & & Max & Min \\
\hline & & $\left(\mathrm{X}_{1}\right)$ & $\left(\mathrm{X}_{2}\right)$ & $\left(\mathrm{X}_{3}\right)$ & $\left(\mathrm{X}_{4}\right)$ & $\left(\mathrm{X}_{5}\right)$ & $\left(\mathrm{X}_{6}\right)$ & $\left(\mathrm{X}_{7}\right)$ & $\left(\mathrm{X}_{8}\right)$ & $\left(\mathrm{X}_{9}\right)$ \\
\hline \multirow{2}{*}{$0^{\#}$} & Retention ratio ${ }^{\circ}$ & -0.04 & 0.20 & $-0.31^{*}$ & -0.14 & 0.12 & -0.20 & 0.01 & -0.04 & 0.17 \\
\hline & No. of bolls & $-0.42^{* *}$ & 0.02 & $-0.37^{* *}$ & $-0.59^{* *}$ & -0.13 & $-0.36^{* *}$ & $-0.36^{* *}$ & 0.01 & $0.46^{* *}$ \\
\hline \multirow{2}{*}{1} & Retention ratio & -0.10 & -0.03 & -0.22 & -0.21 & -0.15 & -0.05 & -0.04 & -0.02 & 0.23 \\
\hline & No. of bolls & $-0.25^{*}$ & -0.01 & $-0.36^{* *}$ & $-0.63^{* *}$ & -0.15 & $-0.30^{*}$ & $-0.25^{*}$ & 0.06 & $0.44^{* *}$ \\
\hline \multirow{2}{*}{2} & Retention ratio & -0.15 & -0.06 & -0.10 & -0.15 & -0.08 & -0.21 & -0.01 & -0.04 & 0.12 \\
\hline & No. of bolls & -0.18 & -0.01 & $-0.34^{* *}$ & $-0.65^{* *}$ & -0.11 & $-0.25^{*}$ & $-0.32^{*}$ & 0.13 & $0.43^{* *}$ \\
\hline \multirow{2}{*}{3} & Retention ratio & -0.03 & -0.01 & -0.02 & -0.21 & -0.01 & -0.17 & -0.08 & 0.09 & 0.12 \\
\hline & No. of bolls & -0.15 & -0.06 & $-0.30^{*}$ & $-0.62^{* *}$ & -0.05 & $-0.28^{*}$ & $-0.31^{*}$ & 0.14 & $0.33^{* *}$ \\
\hline \multirow{2}{*}{4} & Retention ratio & 0.08 & -0.02 & 0.07 & -0.09 & -0.03 & -0.09 & -0.10 & 0.05 & -0.04 \\
\hline & No. of bolls & -0.15 & -0.05 & $-0.28^{*}$ & $-0.63^{* *}$ & -0.06 & $-0.25^{*}$ & $-0.33^{* *}$ & 0.15 & $0.32^{*}$ \\
\hline \multirow{2}{*}{5} & Retention ratio & 0.23 & -0.03 & 0.12 & -0.06 & -0.06 & -0.01 & -0.11 & 0.01 & -0.16 \\
\hline & No. of bolls & -0.14 & -0.05 & $-0.25^{*}$ & $-0.62^{* *}$ & -0.06 & $-0.24^{*}$ & $-0.35^{* *}$ & 0.15 & $0.31^{*}$ \\
\hline \multirow{2}{*}{6} & Retention ratio & 0.09 & -0.08 & 0.12 & -0.09 & -0.07 & -0.01 & -0.09 & 0.00 & -0.05 \\
\hline & No. of bolls & -0.15 & -0.04 & -0.22 & $-0.61^{* *}$ & -0.08 & $-0.25^{*}$ & $-0.34^{* *}$ & 0.13 & 0.22 \\
\hline \multirow{2}{*}{7} & Retention ratio & -0.03 & -0.12 & 0.12 & -0.10 & -0.11 & -0.01 & -0.04 & -0.03 & 0.02 \\
\hline & No. of bolls & -0.15 & -0.02 & -0.19 & $-0.60^{* *}$ & -0.10 & $-0.29^{*}$ & $-0.32^{*}$ & 0.10 & 0.18 \\
\hline \multirow{2}{*}{8} & Retention ratio & -0.02 & 0.05 & 0.03 & -0.10 & -0.04 & -0.03 & -0.02 & -0.01 & 0.01 \\
\hline & No. of bolls & -0.20 & -0.03 & -0.23 & $-0.61^{* *}$ & -0.10 & $-0.28^{*}$ & $-0.32^{*}$ & 0.19 & 0.22 \\
\hline \multirow{2}{*}{9} & Retention ratio & -0.02 & 0.13 & -0.05 & -0.10 & 0.08 & -0.05 & -0.01 & 0.03 & 0.00 \\
\hline & No. of bolls & -0.24 & -0.04 & $-0.29^{*}$ & $-0.62^{* *}$ & -0.11 & $-0.30^{*}$ & $-0.33^{* *}$ & 0.13 & $0.27^{*}$ \\
\hline \multirow{2}{*}{10} & Retention ratio & -0.04 & 0.12 & -0.08 & -0.09 & 0.05 & 0.11 & -0.02 & 0.04 & 0.02 \\
\hline & No. of bolls & $-0.27^{*}$ & -0.07 & $-0.30^{*}$ & $-0.60^{* *}$ & -0.16 & $-0.34^{* *}$ & $-0.34^{* *}$ & 0.11 & $0.26^{*}$ \\
\hline \multirow{2}{*}{11} & Retention ratio & -0.07 & 0.10 & -0.10 & -0.08 & 0.03 & 0.20 & -0.03 & 0.05 & 0.04 \\
\hline & No. of bolls & $-0.30^{*}$ & -0.12 & $-0.30^{*}$ & $-0.61^{* *}$ & -0.18 & $-0.39^{* *}$ & $-0.36^{* *}$ & 0.10 & $0.27^{*}$ \\
\hline \multirow{2}{*}{12} & Retention ratio & -0.11 & 0.09 & -0.14 & -0.11 & 0.04 & 0.13 & -0.08 & 0.11 & 0.09 \\
\hline & No. of bolls & $-0.32^{*}$ & -0.19 & $-0.26^{*}$ & $-0.60^{* *}$ & -0.22 & $-0.42^{* *}$ & $-0.37^{* *}$ & 0.09 & $0.27^{*}$ \\
\hline \multirow{2}{*}{13} & Retention ratio & -0.14 & 0.09 & -0.17 & -0.18 & 0.06 & -0.06 & -0.14 & 0.16 & 0.12 \\
\hline & No. of bolls & $-0.33^{* *}$ & $-0.26^{*}$ & -0.23 & $-0.59^{* *}$ & $-0.28^{*}$ & $-0.48^{* *}$ & $-0.39^{* *}$ & 0.08 & $0.27^{*}$ \\
\hline \multirow{2}{*}{14} & Retention ratio & -0.11 & -0.04 & -0.10 & -0.13 & -0.15 & -0.05 & -0.09 & 0.01 & 0.12 \\
\hline & No. of bolls & $-0.34^{* *}$ & $-0.32^{*}$ & -0.21 & $-0.61^{* *}$ & $-0.32^{*}$ & $-0.48^{* *}$ & $-0.38^{* *}$ & 0.06 & $0.27^{*}$ \\
\hline \multirow{2}{*}{15} & Retention ratio & -0.08 & -0.11 & 0.02 & -0.08 & -0.22 & -0.05 & -0.02 & -0.03 & 0.12 \\
\hline & No. of bolls & $-0.35^{* *}$ & $-0.37^{* *}$ & -0.18 & $-0.61^{* *}$ & $-0.38^{* *}$ & $-0.48^{* *}$ & $-0.37^{* *}$ & 0.03 & $0.27^{*}$ \\
\hline
\end{tabular}

${ }^{*}$ and ${ }^{* *}$ Significant at $5 \%$ and $1 \%$ levels of significance, respectively. ${ }^{\#} 0=$ Initial time. Retention ratio: (the number of retained bolls obtained from the total number of each daily tagged flowers in all selected plants at harvest/each daily number of tagged flowers in all selected plants) $\times 100$. Diurnal temperature range. ${ }^{\mathrm{z}}$ Wind speed did not show significant effect upon the studied production variables, so it is not reported. Sawan et al. [13]. 
peratures and the diurnal temperature range, and soil surface temperature at $600 \mathrm{~h}$ had a negative correlation with boll production. Their significant effects were observed during the 1 , and $10-15$ days periods for maximum temperature, and the $1-5$, and $9-12$ days periods for the diurnal temperatures range. Meanwhile, the daily minimum temperature and soil surface temperature at $600 \mathrm{~h}$ had a significant negative correlation only during the 13 - 15 days periods. Daily minimum humidity had a significant positive correlation with number of bolls during the first 5 days periods, and the 9 - 15 days periods after anthesis. Daily maximum humidity showed no significant relation to number of bolls produced, and further no significant relation was observed between any of the studied climatic factors and boll retention ratio [13].

The results in the two seasons indicated that evaporation and humidity, followed by sunshine duration had obvious correlation with boll production. From the results obtained, it appeared that the effects of air temperature, and soil surface temperature tended to be masked in the first season, i.e. did not show any significant effects in the first season on the number of bolls per plant. However, these effects were found to be significant in the second season. These seasonal differences in the impacts of the previously mentioned climatic factors on the number of bolls per plant are most likely ascribed to the sensible variation in evaporation values in the two studied seasons where their means were $10.2 \mathrm{~mm} \cdot \mathrm{d}^{-1}$ and $5.9 \mathrm{~mm} \cdot \mathrm{d}^{-1}$ in the first and second seasons, respectively [13].

There is an important question here concerning, if there is a way for forecasting when evaporation values would mask the effect of the previous climatic factors. The answer would be possibly achieved through relating humidity values to evaporation values which are naturally liable to some fluctuations from one season to another [13]. It was found that the ratio between the mean of maximum humidity and the mean of evaporation in the first season was $85.8 / 10.2=8.37$, while in the second season this ratio was 12.4 . On the other hand, the ratio between the mean minimum humidity and the mean of evaporation in the first season was 30.8/10.2 =3.02, while in the second season this ratio was 6.75 (Table 7) [13]. From these ratios it seems that minimum humidity which is closely related to evaporation is more sensitive than the ratio between maximum humidity and evaporation. It can be seen from the results and formulas that when the ratio between minimum humidity and evaporation is small (3:1), the effects of air temperature, and soil surface temperature were hindered by the effect of evaporation, i.e. the effect of these climatic factors were not significant. However, when this ratio is high $(6: 1)$, the effects of these factors were found to be significant. Accordingly, it could be generally stated that the effects of air, and soil surface temperatures could be masked by evaporation when the ratio between minimum humidity and evaporation is less than 4:1 [13].

Evaporation appeared to be the most important climatic factor (in each of the 15-day periods both prior to and after initiation of individual bolls) affecting number of flowers or harvested bolls in Egyptian cotton. High daily evaporation rates could result in water stress that would slow growth and increase shedding rate of flowers and bolls. The second most important climatic factor in our study was humidity. Effect of maximum humidity varied markedly from the first season to the second one, where it was significantly correlated with the dependent variables in the first season, while the inverse pattern was true in the second season. This diverse effect may be due to the differences in the values of this factor in the two seasons; where it was on average $87 \%$ in the first season, and only $73 \%$ in the second season (Table 4). Also, was found that, when the average value of minimum humidity exceeded the half average value of maximum humidity, the minimum humidity can substitute the maximum humidity on affecting number of flowers or harvested bolls. In the first season (Table 4) the average value of minimum humidity was less than half of the value of maximum humidity $(30.2 / 85.6=0.35)$, while in the second season it was higher than half of maximum humidity $(39.1 / 72.9=0.54)[13]$.

The third most important climatic factor in our study was sunshine duration, which showed a significant negative relationship with boll production. The $r$ values of (Tables 5-8) indicated that the relationship between the dependent and independent variables preceding flowering (production stage) generally exceeded in value the relationship between them during the entire and late periods of production stage. In fact, understanding the effects of climatic factors on cotton production during the previously mentioned periods would have marked consequences on the overall level of cotton production, which could be predictable depending on those relationships [13].

\subsubsection{Regression Models}

An attempt was carried out to investigate the effect of climatic factors on cotton production via prediction equations including the important climatic factors responsible for the majority of total variability in cotton flower and boll production. Hence, regression models were established using the stepwise multiple regression technique to express the relationship between each of the number of flowers and bolls/plant and boll retention ratio $(\mathrm{Y})$, with the climatic factors, for each of the 1) 5,2) 10 , and 3) 15 days periods either prior to or after initiation of individual bolls (Tables 9 and 10) [13].

Concerning the effect of prior days the results indi- 
Table 9. The models obtained for the number of flowers and bolls per plant as functions of the climatic data derived from the 5,10 , and 15 days periods prior to flower opening in the two seasons (I, II).

\begin{tabular}{|c|c|c|c|}
\hline Season & $\operatorname{Model}^{\mathrm{z}}$ & $R^{2}$ & Significance \\
\hline \multirow{3}{*}{$\begin{array}{l}\text { First } \\
\text { Flower }\end{array}$} & $\mathrm{Y}_{1}=55.75+0.86 \mathrm{X}_{3}-2.09 \mathrm{X}_{4}-2.23 \mathrm{X}_{7}$ & 0.51 & ** \\
\hline & $Y_{2}=26.76-5.45 X_{4}+1.76 X_{9}$ & 0.42 & ** \\
\hline & $\mathrm{Y}_{3}=43.37-1.02 \mathrm{X}_{4}-2.61 \mathrm{X}_{7}+0.20 \mathrm{X}_{8}$ & 0.52 & ** \\
\hline \multirow{3}{*}{$\begin{array}{l}\text { First } \\
\text { Boll }\end{array}$} & $Y_{1}=43.69+0.34 X_{3}-1.71 X_{4}-1.44 X_{7}$ & 0.43 & $* *$ \\
\hline & $\mathrm{Y}_{2}=40.11-1.82 \mathrm{X}_{4}-1.36 \mathrm{X}_{7}+0.10 \mathrm{X}_{8}$ & 0.48 & $* *$ \\
\hline & $\mathrm{Y}_{3}=31.00-0.60 \mathrm{X}_{4}-2.62 \mathrm{X}_{7}+0.23 \mathrm{X}_{8}$ & 0.47 & $* *$ \\
\hline \multirow{3}{*}{$\begin{array}{l}\text { Second } \\
\text { Flower }\end{array}$} & $\begin{aligned} \mathrm{Y}_{1}= & 18.58+0.39 \mathrm{X}_{3}-0.22 \mathrm{X}_{4} \\
& -1.19 \mathrm{X}_{7}+0.17 \mathrm{X}_{9}\end{aligned}$ & 0.54 & $* *$ \\
\hline & $\begin{aligned} \mathrm{Y}_{2}= & 16.21+0.63 \mathrm{X}_{3}-0.20 \mathrm{X}_{4} \\
& -1.24 \mathrm{X}_{7}+0.16 \mathrm{X}_{9}\end{aligned}$ & 0.61 & $* *$ \\
\hline & $\begin{aligned} \mathrm{Y}_{3}= & 14.72+0.51 \mathrm{X}_{3}-0.20 \mathrm{X}_{4} \\
& -0.85 \mathrm{X}_{7}+0.17 \mathrm{X}_{9}\end{aligned}$ & 0.58 & ** \\
\hline \multirow{3}{*}{$\begin{array}{c}\text { Second } \\
\text { Boll }\end{array}$} & $\begin{aligned} \mathrm{Y}_{1}= & 25.83+0.50 \mathrm{X}_{3}-0.26 \mathrm{X}_{4} \\
& -1.95 \mathrm{X}_{7}+0.15 \mathrm{X}_{9}\end{aligned}$ & 0.61 & ** \\
\hline & $\begin{aligned} \mathrm{Y}_{2}= & 19.65+0.62 \mathrm{X}_{3}-0.25 \mathrm{X}_{4} \\
& -1.44 \mathrm{X}_{7}+0.12 \mathrm{X}_{9}\end{aligned}$ & 0.60 & ** \\
\hline & $\begin{aligned} \mathrm{Y}_{3}= & 15.83+0.60 \mathrm{X}_{3}-0.22 \mathrm{X}_{4} \\
& -1.26 \mathrm{X}_{7}+0.14 \mathrm{X}_{9}\end{aligned}$ & 0.59 & ** \\
\hline
\end{tabular}

${ }^{\mathrm{z}}$ Where $\mathrm{Y}_{1}, \mathrm{Y}_{2}, \mathrm{Y}_{3}=$ number of flowers or bolls per plant at the 5, 10 and 15 days periods before flowering, respectively, $\mathrm{X}_{2}=$ minimum temperature $\left({ }^{\circ} \mathrm{C}\right)$, $\mathrm{X}_{3}=$ diurnal temperature range $\left({ }^{\circ} \mathrm{C}\right), \mathrm{X}_{4}=$ evaporation $\left(\mathrm{mm} \cdot \mathrm{day}^{-1}\right), \mathrm{X}_{7}=$ sunshine duration $\left(\mathrm{h} \cdot \mathrm{day}^{-1}\right), \mathrm{X}_{8}=$ maximum humidity $(\%)$ and $\mathrm{X}_{9}=$ minimum humidity (\%). Sawan et al. [13].

Table 10. The models obtained for the number of bolls per plant as functions of the climatic data derived from the 5, 10, and 15 days periods after flower opening in the two seasons (I, II).

\begin{tabular}{|c|c|c|c|}
\hline Season & Model $^{2}$ & $R^{2}$ & Significance \\
\hline \multirow{3}{*}{ First } & $Y_{1}=16.38-0.41 X_{4}$ & 0.14 & $* *$ \\
\hline & $Y_{2}=16.43-0.41 X_{4}$ & 0.14 & ** \\
\hline & $\mathrm{Y}_{3}=27.83-0.60 \mathrm{X}_{4}-0.88 \mathrm{X}_{9}$ & 0.15 & ** \\
\hline \multirow{3}{*}{ Second } & $\mathrm{Y}_{1}=23.96-0.47 \mathrm{X}_{4}-0.77 \mathrm{X}_{8}$ & 0.44 & ** \\
\hline & $\mathrm{Y}_{2}=18.72-0.58 \mathrm{X}_{4}$ & 0.34 & ** \\
\hline & $=56.09-2.51 \mathrm{X}_{4}-0.49 \mathrm{X}_{6}-1.67 \mathrm{X}_{7}$ & 0.56 & ** \\
\hline
\end{tabular}

${ }^{2}$ Where $Y_{1}, Y_{2}, Y_{3}=$ number of bolls per plant at the 5,10 , and 15 days periods after flowering, respectively, $\mathrm{X}_{4}=$ evaporation $\left(\mathrm{mm} \cdot \mathrm{day}^{-1}\right), \mathrm{X}_{6}=$ soil surface temperature $\left({ }^{\circ} \mathrm{C}\right)$ at $1800, \mathrm{X}_{7}=$ sunshine duration $\left(\mathrm{h} \cdot \mathrm{day}^{-1}\right), \mathrm{X}_{8}=$ maximum humidity (\%) and $\mathrm{X}_{9}=$ minimum humidity (\%). Sawan et al. [13].

cated that evaporation, sunshine duration, and the diurnal temperature range were the most effective and consistent climatic factors affecting cotton flower and boll production (Table 9). The fourth effective climatic factor in this respect was minimum humidity. On the other hand, for the periods after flower the results obtained from the equations (Table 10) indicated that evaporation was the most effective and consistent climatic factor affecting number of harvested bolls [13].

Regression models obtained demonstrate of each independent variable under study as an efficient and important factor. Meanwhile, they explained a sensible proportion of the variation in flower and boll production, as indicated by their $R^{2}$, which ranged between $0.14-0.62$, where most of $R^{2}$ prior to flower opening were about 0.50 and after flowering all but one are less than 0.50 [13].These results agree with Miller et al. [23] in their regression study of the relation of yield with rainfall and temperature. They suggested that the other 0.50 of variation related to management practices, which can be the same in this study. Also, the regression models indicated that the relationships between the number of flowers and bolls per plant and the studied climatic factors for the 15 days period before or after flowering $\left(\mathrm{Y}_{3}\right)$ in each season explained the highly significant magnitude of variation $(P<0.05)$. The $R^{2}$ values for the 15 days periods before and after flowering were higher than most of those obtained for each of the 5 and the 10 days periods before or after flowering. This clarifies that the effects of the climatic factors during the 15 days periods before or after flowering are very important for Egyptian cotton boll production and retention. Thus, an accurate climatic forecast for the effect of these 15 days periods provides an opportunity to avoid any possible adverse effects of unusual climatic conditions before flowering or after boll formation by utilizing additional treatments and/or adopting proper precautions to avoid flower and boll reduction.

The main climatic factors from this study affecting the number of flowers and bolls, and by implication yield, are evaporation, sunshine duration and minimum humidity, with evaporation (water stress) being by far the most important factor. Various activities have been suggested to partially overcome water stress. Temperature conditions during the reproduction growth stage of cotton in Egypt do not appear to limit growth even though they are above the optimum for cotton growth [13]. This is contradictory to the finding of Holaday et al. [24]. A possible reason for that contradiction is that the effects of evaporation rate and humidity were not taken into consideration in the research studies conducted by other researchers in other countries. The matter of fact is that temperature and evaporation are closely related to each other to such an extent that the higher evaporation rate could possible mask the effect of temperature. Sunshine duration and minimum humidity appeared to have secondary effects, yet they are in fact important players [13]. The importance of sunshine duration has been alluded to 
by Oosterhuis [25]. Also, Mergeai and Demol [26] found that cotton yield was assisted by intermediate relative humidity.

\subsection{Cotton Flower and Boll Production as Affected by Climatic Factors and Soil Moisture Status}

\section{Basic Variables} [14].

1) Dependant variables as defined above: $\left(Y_{1}\right)$ and $\left(Y_{2}\right)$

2) Independent variables $\left(X_{s}\right)$ :

a) Irrigation on day $1=1$. Otherwise, enter 0.0 (soil moisture status) $\left(\mathrm{X}_{1}\right)$.

b) The first and second days after the day of irrigation (soil moisture status) $=1$. Otherwise, enter $0.0\left(\mathrm{X}_{2}\right)$.

c) The day prior to the day of irrigation (soil moisture status) to check for possible moisture deficiency on that day $=1$. Otherwise, enter $0.0\left(\mathrm{X}_{3}\right)$.

d) Number of days during days 1 (day of flowering)12 (after flowering) that temperature equaled or exceeded $37.5^{\circ} \mathrm{C}$ (high temperature) $\left(\mathrm{X}_{4}\right)$.

e) Range of temperature (diurnal temperature) $\left[{ }^{\circ} \mathrm{C}\right]$ on day 1 (day of flowering) $\left(\mathrm{X}_{5}\right)$.

f) Broadest range of temperature $\left[{ }^{\circ} \mathrm{C}\right]$ over days 1 (day of flowering)-12 (after flowering) $\left(\mathrm{X}_{6}\right)$.

g) Minimum relative humidity (min $\mathrm{RH}$ ) [\%] during day 1 (day of flowering) $\left(\mathrm{X}_{7}\right)$.

h) Maximum relative humidity (max $\mathrm{RH})$ [\%] during day 1 (day of flowering) $\left(\mathrm{X}_{8}\right)$.

i) Minimum relative humidity ( $\mathrm{min} \mathrm{RH}$ ) [\%] during day 2 (after flowering) $\left(\mathrm{X}_{9}\right)$.

j) Maximum relative humidity $(\max \mathrm{RH})[\%]$ during day 2 (after flowering) $\left(\mathrm{X}_{10}\right)$.

k) Largest maximum relative humidity (max RH) [\%] on days 3 - 6 (after flowering) ( $\mathrm{X}_{11}$ ).

1) Lowest minimum relative humidity (min $\mathrm{RH}$ ) [\%] on days 3 - 6 (after flowering) $\left(\mathrm{X}_{12}\right)$.

m) Largest maximum relative humidity (max $\mathrm{RH})$ [\%] on days 7 - 12 (after flowering) $\left(\mathrm{X}_{13}\right)$.

n) Lowest minimum relative humidity (min $\mathrm{RH})$ [\%] on days 7 - 12 (after flowering) $\left(\mathrm{X}_{14}\right)$.

o) Lowest minimum relative humidity $(\mathrm{min} \mathrm{RH})$ [\%] on days 50 - 52 (after flowering) $\left(\mathrm{X}_{15}\right)$.

p) Daily light period (hour) $\left(\mathrm{X}_{16}\right)$.

\section{Statistical Analysis}

Simple correlation coefficients between the initial group of independent variables (climatic factors and soil moisture status) (X's) and the corresponding dependent variables (Y's) were computed for each season and the combined data of the two seasons. These correlation coefficients helped determine the significant climatic factors and soil moisture status affecting the cotton production variables. The level for significance was $P \leq 0.15$.
Those climatic factors and soil moisture status attaining a probability level of significance not exceeding 0.15 were deemed important (affecting the dependent variables) [14]. Those factors were combined with dependent variables in multiple regression analysis to obtain a predictive model as described by Cady and Allen [16]. Multiple linear regression equations (using the stepwise method) comprising selected predictive variables were computed for the determined interval. Coefficients of multiple determinations $\left(R^{2}\right)$ were calculated to measure the efficiency of the regression models in explaining the variation in data. Correlation and regression analysis were computed according to Draper and Smith [17] using the procedures outlined in the general linear model (GLM) [15].

\subsubsection{Correlation Estimates}

Simple correlation coefficients between the independent variables and the dependent variables for flower and boll production in each season and combined data of the two seasons are shown in Tables 11-13 [14]. The simple correlation values indicated clearly that relative humidity was the most important climatic factor. Relative humidity also had a significant positive relationship with flower and boll production; except for lowest min RH on days 50 - 52 (after flowering) [14]. Flower and boll production were positively and highly correlated with the variables of largest max $\mathrm{RH}\left(\mathrm{X}_{11}, \mathrm{X}_{13}\right)$ and lowest min RH $\left(\mathrm{X}_{14}, \mathrm{X}_{15}\right)$ in the first season, min RH $\left(\mathrm{X}_{7}, \mathrm{X}_{9}\right)$, largest max RH $\left(\mathrm{X}_{11}\right)$, and lowest min $\mathrm{RH}\left(\mathrm{X}_{12}, \mathrm{X}_{14}, \mathrm{X}_{15}\right)$ in the second season, and the combined data of the two seasons [14]. Effect of max RH varied markedly from the first to the second season. Max RH was significantly correlated with the dependent variables in the first season, while the inverse pattern was true in the second season. This diverse effect may be best explained by the differences of $87 \%$ in the first season, and only $73 \%$ in the second season (Table 1). Also, when the average value of min RH exceeded the half average value of max RH, the min RH can substitute for the max RH on affecting number of flowers or harvested bolls. In the first season (Table 1) the average value of min RH was less than half of the value of max RH $(30.2 / 85.6=0.35)$, while in the second season it was higher than half of max RH $(39.1 / 72.9=0.54)$. Sunshine duration $\left(\mathrm{X}_{16}\right)$ showed a significant negative relation with fruit production in the first and second seasons and the combined data of the two seasons except for boll production in the first season, which was not significant. Flower and boll production were negatively correlated in the second season and the combined data of the two seasons with the number of days during days 1 - 12 that temperature equaled or exceeded $37.5^{\circ} \mathrm{C}\left(\mathrm{X}_{4}\right)$, range of temperature (diurnal 
Table 11. Simple correlation coefficient $(r)$ values between the independent variables and the dependent variables in the first season (I).

\begin{tabular}{|c|c|c|}
\hline \multirow{2}{*}{$\begin{array}{c}\text { Independent variables } \\
\text { (Irrigation and climatic factors) }\end{array}$} & \multicolumn{2}{|c|}{$\begin{array}{l}\text { Dependent variables } \\
\text { (First season) }\end{array}$} \\
\hline & Flowers & Bolls \\
\hline$\left(\mathrm{X}_{1}\right)$ Irrigation on day 1 & -0.1282 & -0.0925 \\
\hline $\begin{array}{c}\left(\mathrm{X}_{2}\right) \text { Irrigation on day } 0 \text { or }-1\left(1^{\text {st }} \text { and }\right. \\
\left.2^{\text {nd }} \text { day after irrigation }\right)\end{array}$ & -0.1644 & -0.1403 \\
\hline$\left(\mathrm{X}_{3}\right) 1$ is for the day prior to irrigation & -0.0891 & -0.0897 \\
\hline $\begin{array}{l}\left(\mathrm{X}_{4}\right) \text { Number of days that temperature } \\
\text { equaled or exceeded } 37.5^{\circ} \mathrm{C}\end{array}$ & 0.1258 & 0.1525 \\
\hline$\left(\mathrm{X}_{5}\right)$ Range of temperature $\left[{ }^{\circ} \mathrm{C}\right]$ on day 1 & -0.0270 & -0.0205 \\
\hline $\begin{array}{c}\left(\mathrm{X}_{6}\right) \text { Broadest range of temperature } \\
{\left[{ }^{\circ} \mathrm{C}\right] \text { over days } 1-12}\end{array}$ & 0.0550 & $0.1788^{\mathrm{d}}$ \\
\hline$\left(\mathrm{X}_{7}\right)$ Min RH [\%] during day 1 & 0.1492 & 0.1167 \\
\hline$\left(\mathrm{X}_{8}\right)$ Max RH [\%] during day 1 & $0.2087^{\mathrm{c}}$ & 0.1531 \\
\hline$\left(\mathrm{X}_{9}\right)$ Min RH [\%] during day 2 & 0.1079 & 0.1033 \\
\hline$\left(\mathrm{X}_{10}\right)$ Max RH [\%] during day 2 & 0.1127 & 0.0455 \\
\hline$\left(\mathrm{X}_{11}\right)$ Largest max RH [\%] on days 3 - 6 & $0.3905^{\mathrm{a}}$ & $0.2819^{\mathrm{b}}$ \\
\hline$\left(\mathrm{X}_{12}\right)$ Lowest min $\mathrm{RH}[\%]$ on days 3 - 6 & 0.0646 & 0.0444 \\
\hline$\left(\mathrm{X}_{13}\right)$ Largest max RH [\%] on days 7 - 12 & $0.4499^{\mathrm{a}}$ & $0.3554^{\mathrm{b}}$ \\
\hline$\left(\mathrm{X}_{14}\right)$ Lowest $\min \mathrm{RH}[\%]$ on days $7-12$ & $0.3522^{\mathrm{a}}$ & $0.1937^{\mathrm{d}}$ \\
\hline$\left(\mathrm{X}_{15}\right)$ Lowest $\min \mathrm{RH}[\%]$ on days $50-52$ & $-0.3440^{\mathrm{a}}$ & $-0.4222^{\mathrm{a}}$ \\
\hline$\left(\mathrm{X}_{16}\right)$ Daily light period (hour) & $-0.2430^{\mathrm{b}}$ & -0.1426 \\
\hline
\end{tabular}

${ }^{a}$ Significant at $1 \%$ probability level. ${ }^{b}$ Significant at $5 \%$ probability level. ${ }^{\mathrm{c}}$ Significant at $10 \%$ probability level. ${ }^{\mathrm{d}}$ Significant at $15 \%$ probability level. Sawan et al. [14].

temperature) on flowering day $\left(\mathrm{X}_{5}\right)$ and broadest range of temperature over days $1-12\left(\mathrm{X}_{6}\right)$. The soil moisture status showed low and insignificant correlation with flower and boll production. The positive relationship between relative humidity with flower and boll production means that low relative humidity rate reduces significantly cotton flower and boll production. This may be due to greater plant water deficits when relative humidity decreases. Also, the negative relationship between the variables of maximum temperature exceeding $37.5^{\circ} \mathrm{C}$ $\left(\mathrm{X}_{4}\right)$, range of diurnal temperature on flowering $\left(\mathrm{X}_{5}\right)$, and sunshine duration $\left(\mathrm{X}_{16}\right)$ with flower and boll production revealed that the increased values of these factors had a detrimental effect upon Egyptian cotton fruit production. Results obtained from the production stage of each season, and the combined data of the two seasons showed marked variability in the relationships of some climatic variables with the dependent variables [14]. This may be
Table 12. Simple correlation coefficient $(r)$ values between the independent variables and the dependent variables in the second season (II).

\begin{tabular}{|c|c|c|}
\hline \multirow{2}{*}{$\begin{array}{l}\text { Independent variables } \\
\text { (Irrigation and climatic factors) }\end{array}$} & \multicolumn{2}{|c|}{$\begin{array}{l}\text { Dependent variables } \\
\text { (Second season) }\end{array}$} \\
\hline & Flowers & Bolls \\
\hline$\left(\mathrm{X}_{1}\right)$ Irrigation on day 1 & -0.0536 & -0.0467 \\
\hline$\left(\mathrm{X}_{2}\right)$ Irrigation on day 0 or -1 & -0.1116 & -0.1208 \\
\hline $\begin{array}{c}\left(\mathrm{X}_{3}\right) 1 \text { is for the day prior to the } \\
\text { day of irrigation }\end{array}$ & -0.0929 & -0.0927 \\
\hline $\begin{array}{l}\left(\mathrm{X}_{4}\right) \text { Number of days that temperature } \\
\text { equaled or exceeded } 37.5^{\circ} \mathrm{C}\end{array}$ & $-0.4192^{\mathrm{a}}$ & $-0.3981^{\mathrm{a}}$ \\
\hline$\left(\mathrm{X}_{5}\right)$ Range of temperature $\left[{ }^{\circ} \mathrm{C}\right]$ on day 1 & $-0.3779^{\mathrm{a}}$ & $-0.3858^{\mathrm{a}}$ \\
\hline $\begin{array}{c}\left(\mathrm{X}_{6}\right) \text { Broadest range of temperature }\left[{ }^{\circ} \mathrm{C}\right] \\
\text { over days } 1-12\end{array}$ & $-0.3849^{\mathrm{a}}$ & $-0.3841^{\mathrm{a}}$ \\
\hline$\left(\mathrm{X}_{7}\right)$ Min $\mathrm{RH}[\%]$ during day 1 & $0.4522^{\mathrm{a}}$ & $0.4665^{\mathrm{a}}$ \\
\hline$\left(\mathrm{X}_{8}\right)$ Max RH [\%] during day 1 & 0.0083 & 0.0054 \\
\hline$\left(\mathrm{X}_{9}\right)$ Min $\mathrm{RH}[\%]$ during day 2 & $0.4315^{\mathrm{a}}$ & $0.4374^{\mathrm{a}}$ \\
\hline$\left(\mathrm{X}_{10}\right)$ Max RH [\%] during day 2 & 0.0605 & 0.0532 \\
\hline$\left(\mathrm{X}_{11}\right)$ Largest max RH [\%] on days $3-6$ & $0.2486^{\mathrm{c}}$ & $0.2520^{\mathrm{b}}$ \\
\hline$\left(\mathrm{X}_{12}\right)$ Lowest $\min \mathrm{RH}[\%]$ on days $3-6$ & $0.5783^{\mathrm{a}}$ & $0.5677^{\mathrm{a}}$ \\
\hline$\left(\mathrm{X}_{13}\right)$ Largest max RH [\%] on days $7-12$ & 0.0617 & 0.0735 \\
\hline$\left(\mathrm{X}_{14}\right)$ Lowest $\min \mathrm{RH}[\%]$ on days $7-12$ & $0.4887^{\mathrm{a}}$ & $0.4691^{\mathrm{a}}$ \\
\hline$\left(\mathrm{X}_{15}\right)$ Lowest $\min \mathrm{RH}[\%]$ on days $50-52$ & $-0.6246^{\mathrm{a}}$ & $-0.6113^{\mathrm{a}}$ \\
\hline$\left(\mathrm{X}_{16}\right)$ Daily light period (hour) & $-0.3677^{\mathrm{a}}$ & $-0.3609^{\mathrm{a}}$ \\
\hline
\end{tabular}

${ }^{a}$ Significant at $1 \%$ probability level. ${ }^{\text {b }}$ Significant at $5 \%$ probability level. ${ }^{\mathrm{c}}$ Significant at $10 \%$ probability level. Sawan et al. [14].

best explained by the differences between climatic factors in the two seasons as illustrated by the ranges and means shown in Table 1. For example, maximum temperature exceeding $37.5^{\circ} \mathrm{C}\left(\mathrm{X}_{4}\right)$ and $\mathrm{min} \mathrm{RH}$ did not show significant relations in the first season, while that trend differed in the second season [14].

These results indicated that relative humidity was the most effective and consistent climatic factor affecting boll production. The second most important climatic factor in our study was sunshine duration, which showed a significant negative relationship with boll production [14].

Human et al. [22] stated that, when sunflower plants were grown under controlled temperature regimes and water stress during budding, anthesis and seed filling, the $\mathrm{CO}_{2}$ uptake rate per unit leaf area as well as total uptake rate per plant, significantly diminished with stress, while this effect resulted in a significant decrease in yield per plant. 
Table 13. Simple correlation coefficient $(r)$ values between the independent variables and dependent variables in the combined two seasons (I and II).

\begin{tabular}{|c|c|c|}
\hline \multirow{2}{*}{$\begin{array}{l}\text { Independent variables } \\
\text { (Irrigation and climatic factors) }\end{array}$} & \multicolumn{2}{|c|}{$\begin{array}{l}\text { Dependent variables } \\
\text { (Combined two seasons) }\end{array}$} \\
\hline & Flowers & Bolls \\
\hline$\left(\mathrm{X}_{1}\right)$ Irrigation on day 1 & -0.0718 & -0.0483 \\
\hline$\left(\mathrm{X}_{2}\right)$ Irrigation on day 0 or -1 & -0.1214 & -0.1108 \\
\hline $\begin{array}{c}\left(\mathrm{X}_{3}\right) 1 \text { is for the day prior to the day } \\
\text { of irrigation }\end{array}$ & -0.0845 & -0.0769 \\
\hline $\begin{array}{l}\left(\mathrm{X}_{4}\right) \text { Number of days that temperature } \\
\text { equaled or exceeded } 37.5^{\circ} \mathrm{C}\end{array}$ & $-0.2234^{b}$ & $-0.1720^{\mathrm{c}}$ \\
\hline$\left(\mathrm{X}_{5}\right)$ Range of temperature $\left[{ }^{\circ} \mathrm{C}\right]$ on day 1 & $-0.2551^{\mathrm{a}}$ & $-0.2479^{\mathrm{a}}$ \\
\hline $\begin{array}{c}\left(\mathrm{X}_{6}\right) \text { Broadest range of temperature }\left[{ }^{\circ} \mathrm{C}\right] \\
\text { over days } 1-12\end{array}$ & $-0.2372^{\mathrm{a}}$ & $-0.1958^{b}$ \\
\hline$\left(\mathrm{X}_{7}\right)$ Min $\mathrm{RH}[\%]$ during day 1 & $0.3369^{\mathrm{a}}$ & $0.3934^{\mathrm{a}}$ \\
\hline$\left(\mathrm{X}_{8}\right)$ Max RH [\%] during day 1 & 0.0032 & -0.0911 \\
\hline$\left(\mathrm{X}_{9}\right)$ Min RH [\%] during day 2 & $0.3147^{\mathrm{a}}$ & $0.3815^{\mathrm{a}}$ \\
\hline$\left(\mathrm{X}_{10}\right)$ Max RH[\%] during day 2 & -0.0094 & -0.1113 \\
\hline$\left(\mathrm{X}_{11}\right)$ Largest max RH [\%] on days $3-6$ & 0.0606 & -0.0663 \\
\hline$\left(\mathrm{X}_{12}\right)$ Lowest min $\mathrm{RH}[\%]$ on days $3-6$ & $0.3849^{\mathrm{a}}$ & $0.4347^{\mathrm{a}}$ \\
\hline$\left(\mathrm{X}_{13}\right)$ Largest max RH [\%] on days $7-12$ & -0.0169 & $-0.1442^{\mathrm{d}}$ \\
\hline$\left(\mathrm{X}_{14}\right)$ Lowest $\min \mathrm{RH}[\%]$ on days $7-12$ & $0.3891^{\mathrm{a}}$ & $0.4219^{\mathrm{a}}$ \\
\hline$\left(\mathrm{X}_{15}\right)$ Lowest $\min \mathrm{RH}[\%]$ on days 50 - 52 & $-0.3035^{\mathrm{a}}$ & $-0.2359^{\mathrm{a}}$ \\
\hline$\left(\mathrm{X}_{16}\right)$ Daily light period (hour) & $-0.3039^{\mathrm{a}}$ & $-0.2535^{\mathrm{a}}$ \\
\hline
\end{tabular}

${ }^{a}$ Significant at $1 \%$ probability level. ${ }^{\text {b }}$ Significant at $5 \%$ probability level. ${ }^{\mathrm{c}}$ Significant at $10 \%$ probability level. ${ }^{\mathrm{d}}$ Significant at $15 \%$ probability level. Sawan et al. [14].

\subsubsection{Multiple Linear Regression Models, Beside Contribution of Climate Factors and Soil Moisture Status to Variations in the Dependent Variables}

Regression models were established using the stepwise multiple regression technique to express the relationship between the number of flowers and bolls per plant $^{-1}(\mathrm{Y})$ with the climatic factors and soil moisture status (Table 14). Relative humidity (\%) was the most important climatic factor affecting flower and boll production in Egyptian cotton [min RH during day $1\left(\mathrm{X}_{7}\right)$, min RH during day $2\left(\mathrm{X}_{9}\right)$, largest max RH on days 3 - 6 $\left(\mathrm{X}_{11}\right)$, lowest min $\mathrm{RH}$ on days 3 - $6\left(\mathrm{X}_{12}\right)$, largest max RH on days $7-12\left(\mathrm{X}_{13}\right)$, lowest min RH on days $7-12\left(\mathrm{X}_{14}\right)$ and lowest min RH on days 50 - $\left.52\left(\mathrm{X}_{15}\right)\right]$. Sunshine duration $\left(\mathrm{X}_{16}\right)$ was the second climatic factor of importance affecting production of flowers and bolls. Maximum temperature $\left(\mathrm{X}_{4}\right)$, broadest range of temperature $\left(\mathrm{X}_{6}\right)$ and soil moisture status $\left(\mathrm{X}_{1}\right)$ made a contribution affecting flower and boll production. The soil moisture variables $\left(\mathrm{X}_{2}, \mathrm{X}_{3}\right)$, and climatic factors $\left(\mathrm{X}_{5}, \mathrm{X}_{8}, \mathrm{X}_{10}\right)$ were not included in the equations since they had very little effects on production of cotton flowers and bolls [14].

Relative humidity showed the highest contribution to the variation in both flower and boll production (Table 14). This finding can be explained in the light of results found by Ward and Bunce [27] in sunflower (Helianthus annuus). They stated that decreases of relative humidity on both leaf surfaces reduced photosynthetic rate of the whole leaf for plants grown under a moderate temperature and medium light level.

Gutiérrez and López [28] studied the effects of heat on the yield of cotton in Andalucia, Spain, during 1991-98, and found that high temperatures were implicated in the reduction of unit production. There was a significant negative relationship between average production and number of days with temperatures greater than $40^{\circ} \mathrm{C}$ and the number of days with minimum temperatures greater than $20^{\circ} \mathrm{C}$. Wise et al. [29] indicated that restrictions to photosynthesis could limit plant growth at high temperature in a variety of ways. In addition to increasing photorespiration, high temperatures $\left(35^{\circ} \mathrm{C}-42^{\circ} \mathrm{C}\right)$ can cause direct injury to the photosynthetic apparatus. Both carbon metabolism and thylakoid reactions have been suggested as the primary site of injury at these temperatures.

Regression models obtained explained a sensible proportion of the variation in flower and boll production, as indicated by their $R^{2}$, which ranged between $0.53-0.72$ [14]. These results agree with Miller et al. [23] in their regression study of the relation of yield with rainfall and temperature. They suggested that the other $R^{2} 0.50$ of variation was related to management practices, which coincide with the findings of this study. Thus, an accurate climatic forecast for the effect of the 5 - 7 days period during flowering may provide an opportunity to avoid possible adverse effects of unusual climatic conditions before flowering or after boll formation by utilizing additional treatments and/or adopting proper precautions to avoid flower and boll reduction.

Temperature conditions during the reproduction growth stage of cotton in Egypt do not appear to limit this growth even though they are above the optimum for cotton growth [14]. This is contradictory to the finding of Holaday et al. [24]. A possible reason for that contradiction is that the effects of soil moisture status and relative humidity were not taken into consideration in the research studies conducted by other researchers in other countries. Since temperature and evaporation are closely related to each other, the higher evaporation rate could possibly mask the effect of temperature. Sunshine duration and minimum relative humidity appeared to have secondary effects, yet they are in fact important factors. 
Table 14. Model obtained for cotton production variables as functions of climatic data and soil moisture status in individual and combined seasons. All entries significant at $1 \%$ level.

\begin{tabular}{cccc}
\hline Season & Model & $R^{2}$ \\
\hline $\begin{array}{c}\text { Season I } \\
(\mathrm{n}=68)\end{array}$ & $\mathrm{Y}_{1}=-557.54+6.35 \mathrm{X}_{6}+0.65 \mathrm{X}_{7}+1.92 \mathrm{X}_{11}+4.17 \mathrm{X}_{13}+2.88 \mathrm{X}_{14}-1.90 \mathrm{X}_{15}-5.63 \mathrm{X}_{16}$ & 0.63 \\
& $Y_{2}=-453.93+6.53 \mathrm{X}_{6}+0.61 \mathrm{X}_{7}+1.80 \mathrm{X}_{11}+2.47 \mathrm{X}_{13}+1.87 \mathrm{X}_{14}-1.85 \mathrm{X}_{15}$ & 0.53 & \\
$\begin{array}{c}\text { Season II } \\
(\mathrm{n}=62)\end{array}$ & $\mathrm{Y}_{1}=-129.45+25.36 \mathrm{X}_{1}+37.02 \mathrm{X}_{4}+1.48 \mathrm{X}_{7}+1.69 \mathrm{X}_{9}+4.46 \mathrm{X}_{12}+2.55 \mathrm{X}_{14}-4.73 \mathrm{X}_{15}$ & 0.72 \\
& $\mathrm{Y}_{2}=-130.23+24.27 \mathrm{X}_{1}+35.66 \mathrm{X}_{4}+1.42 \mathrm{X}_{7}+1.61 \mathrm{X}_{9}+4.00 \mathrm{X}_{12}+2.18 \mathrm{X}_{14}-4.09 \mathrm{X}_{15}$ & 0.71 \\
$\begin{array}{c}\text { Combined data: } \mathbf{I} \& \text { II } \\
(\mathrm{n}=130)\end{array}$ & $\mathrm{Y}_{1}=-557.36+6.82 \mathrm{X}_{6}+1.44 \mathrm{X}_{7}+0.75 \mathrm{X}_{9}+2.04 \mathrm{X}_{11}+2.55 \mathrm{X}_{12}+2.01 \mathrm{X}_{13}+3.27 \mathrm{X}_{14}-2.15 \mathrm{X}_{15}$ & 0.57 & 0.53 \\
\hline
\end{tabular}

$\left(\mathrm{Y}_{1}\right)$ Number of cotton flowers; $\left(\mathrm{Y}_{2}\right)$ Number of cotton bolls. $\left(\mathrm{X}_{1}\right)$ Irrigation on day $1 ;\left(\mathrm{X}_{4}\right)$ Number of that temperature equaled or exceeded $37.5^{\circ} \mathrm{C} ;\left(\mathrm{X}_{6}\right)$ Broadest range of temperature $\left[{ }^{\circ} \mathrm{C}\right.$ ] over days 1 - 12; $\left(\mathrm{X}_{7}\right)$ Min RH [\%] during day 1; $\left(\mathrm{X}_{9}\right)$ Min RH [\%] during day 2; $\left(\mathrm{X}_{11}\right)$ Largest max RH [\%] on days 3 - 6; $\left(\mathrm{X}_{12}\right)$ Lowest min RH [\%] on days $3-6$; $\left(\mathrm{X}_{13}\right)$ Largest max RH [\%] on days $7-12 ;\left(\mathrm{X}_{14}\right)$ Lowest min RH [\%] on days 7 - 12; $\left(\mathrm{X}_{15}\right)$ Lowest min RH [\%] on days 50 - 52; $\left(\mathrm{X}_{16}\right)$ Daily light period (hour). Sawan et al. [14].

\section{CONCLUSIONS}

Evaporation, sunshine duration, relative humidity, surface soil temperature at $1800 \mathrm{~h}$, and maximum temperature, were the most significant climatic factors affecting flower and boll production of Egyptian cotton. Also, it could be concluded that during the 15-day period both prior to and after initiation of individual bolls, evaporation, minimum relative humidity and sunshine duration, were the most significant climatic factors affecting cotton flower and boll production and retention in Egyptian cotton [13]. The negative correlation between each of evaporation and sunshine duration with flower and boll formation along with the positive correlation between minimum relative humidity value and flower and boll production, indicate that low evaporation rate, short period of sunshine duration and high value of minimum humidity would enhance flower and boll formation [13]. Water stress is in fact the main player and other authors have suggested means for overcoming its adverse effect which could be utilized in the Egyptian cotton. It must be kept in mind that although the reliable prediction of the effects of the aforementioned climatic factors could lead to higher yields of cotton, yet only $50 \%$ of the variation in yield could be statistically explained by these factors and hence consideration should also be given to the management practices presently in use. The 5-day interval was found to give adequate and sensible relationships between climatic factors and cotton production growth under Egyptian conditions when compared with other intervals and daily observations [12]. It may be concluded that the 5-day accumulation of climatic data during the production stage, in the absence of sharp fluctuations in these factors, could be satisfactorily used to forecast adverse effects on cotton production and the application of appropriate production practices circumvent possible production shortage. Evaporation and sunshine duration appeared to be important climatic factors af- fecting boll production in Egyptian cotton. Our findings indicate that increasing evaporation rate and sunshine duration resulted in lower boll production. On the other hand, relative humidity, which had a positive correlation with boll production, was also an important climatic factor. In general, increased relative humidity would bring about better boll production. Temperature appeared to be less important in the reproduction growth stage of cotton in Egypt than min RH (water stress) and sunshine duration. These findings concur with those of other researchers, except for the importance of temperature. A possible reason for that contradiction is that the effects of evaporation rate and relative humidity were not taken into consideration in the research studies conducted by other researchers in other countries. Since temperature and evaporation are closely related to each other, the higher evaporation rate could possibly mask the effect of temperature.

Finally, the early prediction of possible adverse effects of climatic factors might modify their effect on production of Egyptian cotton. Minimizing deleterious effects through the application of proper management practices, such as, adequate irrigation regime, and utilization of specific plant growth regulators could limit the negative effects of some climatic factors [14].

\section{REFERENCES}

[1] El-Zik, K.M. (1980) The cotton plant-Its growth and development. Western Cotton Prod. Conf. Summary Proc., Fresno, 18-21.

[2] Guinn, G. (1982) Causes of square and boll shedding in cotton. USDA Tech. Bull. 1672. USDA, Washington, DC.

[3] Hodges, H.F., Reddy, K.R., McKinion, J.M. and Reddy, V.R. (1993) Temperature effects on cotton. Bulletin Mississippi Agricultural and Forestry Experiment Station, No. 990, 15.

[4] Xiao, J.-F., Liu, Z.-G., Yu, X.-G., Zhang, J.-Y. and Duan, 
A.-W. (2000) Effects of different water application on lint yield and fiber quality of cotton under drip irrigation. Acta Gossypii Sinica, 12, 194-197.

[5] Barbour, M.M. and Farquhar, G.D. (2000) Relative humidity- and ABA-induced variation in carbon and oxygen isotope ratios of cotton leaves. Plant, Cell and Environment, 23, 473-485. http://dx.doi.org/10.1046/j.1365-3040.2000.00575.x

[6] Reddy, K.R., Hodges, H.F. and McKinion, J.M. (1995) Carbon dioxide and temperature effects on pima cotton growth. Agriculture Ecosystems \& Environment, 54, 1729. http://dx.doi.org/10.1016/0167-8809(95)00593-H

[7] Schrader, S.M., Wise, R.R., Wacholtz, W.F., Ort, D.R. and Sharkey, T.D. (2004) Thylakoid membrane responses to moderately high leaf temperature in Pima Cotton. Plant, Cell and Environment, 27, 725-735. http://dx.doi.org/10.1111/j.1365-3040.2004.01172.x

[8] Zhou, Z.-G., Meng, Y.-L., Shi Pei, Shen, Y.-Q. and Jia, Z.K. (2000) Study of the relationship between boll weight in wheat-cotton double cropping and meteorological factors at boll-forming stage. Acta Gossypii Sinica, 12, 122126.

[9] Fisher, W.D. (1975) Heat induced sterility in Upland cotton. Proceedings of 27 th Cotton Improvement Conference, 85 .

[10] Zhao, Y.-Z. (1981) Climate in Liaoning and cotton production. Liaoning Agricultural Science, 5, 1-5.

[11] Reddy, K.R., Robana, R.R., Hodges, H.F., Liu, X.-J. and Mckinion, J.M. (1998) Interactions of $\mathrm{CO}_{2}$ enrichment and temperature on cotton growth and leaf characteristics. Environmental and Experimental Botany, 39, 117-129. http://dx.doi.org/10.1016/S0098-8472(97)00028-2

[12] Sawan, Z.M., Hanna, L.I. and McCuistions, W.L. (2006) Appropriate time scale for aggregating climatic data to predict flowering and boll setting behaviour of cotton in Egypt. Communication in Biometry and Crop Science, 1, 11-19.

[13] Sawan, Z.M., Hanna, L.I. and McCuistions, W.L. (2005) Response of flower and boll development to climatic factors before and after anthesis in Egyptian cotton. Climate Research, 29, 167-179. http://dx.doi.org/10.3354/cr029167

[14] Sawan, Z.M., Hanna, L.I., McCuistions, W.L. and Foote, R.J. (2010) Egyptian cotton (Gossypium barbadense) flower and boll production as affected by climatic factors and soil moisture status. Theoretical and Applied Climatology, 99, 217-227. http://dx.doi.org/10.1007/s00704-009-0138-5

[15] SAS Institute, Inc. (1985) SAS User's Guide: Statistics. 5th Edition, SAS Institute, Inc., Cary, 433-506.

[16] Cady, F.B. and Allen, D.M. (1972) Combining experiments to predict future yield data. Agronomy Journal, 64, 211-214. http://dx.doi.org/10.2134/agronj1972.0002196200640002 $\underline{0025 x}$
[17] Draper, N.R. and Smith, H. (1966) Applied regression analysis. John Wiley \& Sons Ltd., New York, 407 p.

[18] Kaur, R. and Singh, O.S. (1992) Response of growth stages of cotton varieties to moisture stress. Indian Journal of Plant Physiology, 35, 182-185.

[19] Hearn, A.B. and Constable, G.A. (1984) The physiology of tropical food crops. John Wiley \& Sons Ltd., New York, Chapter 14, 495-527.

[20] Bhatt, J.G. (1977) Growth and flowering of cotton (Gossypium hirsutum L.) as affected by daylength and temperature. Journal of Agricultural Science, 89, 583-588. http://dx.doi.org/10.1017/S0021859600061360

[21] Meek, C.R., Oosterhuis, D.M. and Steger, A.T. (1999) Drought tolerance and foliar sprays of glycine betaine. Proceedings Beltwide Cotton Conferences, Orlando, 3-7 January 1999, 559-561.

[22] Human, J.J., Du Toit, D., Bezuidenhout, H.D. and De Bruyn, L.P. (1990) The influence of plant water stress on net photosynthesis and yield of sunflower (Helianthus annuus L.). Journal of Agronomy and Crop Science, 164, 231-241. http://dx.doi.org/10.1111/j.1439-037X.1990.tb00812.x

[23] Miller, J.K., Krieg, D.R. and Paterson, R.E. (1996) Relationship between dryland cotton yields and weather parameters on the Southern Hig Plains. Proceedings Beltwide Cotton Conferences, Nashville, 9-12 January 1996, 1165-1166.

[24] Holaday, A.S., Haigler, C.H., Srinivas, N.G., Martin, L.K. and Taylor, J.G. (1997) Alterations of leaf photosynthesis and fiber cellulose synthesis by cool night temperatures. Proceedings Beltwide Cotton Conferences, New Orleans, 6-10 January 1997, 1435-1436.

[25] Oosterhuis, D.M. (1997) Effect of temperature extremes on cotton yields in Arkansas. Proceedings of the Cotton Research Meeting, Monticello, 13 February 1997, 94-98.

[26] Mergeai, G. and Demol, J. (1991) Contribution to the study of the effect of various meteorological factors on production and quality of cotton (Gossypium hirsutum L.) fibers. Bulletin des Recherches Agronomiqued de Gembloux, 26, 113-124.

[27] Ward, D.A. and Bunce, J.A. (1986) Responses of net photosynthesis and conductance to independent changes in the humidity environments of the upper and lower surfaces of leaves of sunflower and soybean. Journal of Experimental Botany, 37, 1842-1853. http://dx.doi.org/10.1093/jxb/37.12.1842

[28] Gutiérrez Mas, J.C. and López, M. (2003) Heat, limitation of yields of cotton in Andalucia. Agricultura, Revista Agropecuaria, 72, 690-692.

[29] Wise, R.R., Olson, A.J., Schrader, S.M. and Sharkey, T.D. (2004) Electron transport is the functional limitation of photosynthesis in field-grown Pima cotton plants at high temperature. Plant, Cell and Environment, 27, 717-724. http://dx.doi.org/10.1111/j.1365-3040.2004.01171.x 